\title{
Some Remarks on the Significance of Gold Based ON BYZANTINE EKPHRASEIS OF WORKS OF ART
}

\begin{abstract}
G old is considered one of the most characteristic elements of Byzantine culture. This view applies especially to art. Undoubtedly, this statement is quite right: it is best confirmed by the preserved works of painting and artistic craftsmanship, especially those of jewellery. In sum, Byzantine artists used to use gold on a large scale, showing great technical skill. It is therefore surprising that this issue has not received a separate and comprehensive study yet ${ }^{1}$. Although researchers recognise the presence of gold, unfortunately, they rarely go beyond the general observations ${ }^{2}$. Despite this, in the literature devoted to Byzantine art,
\end{abstract}

\footnotetext{
${ }^{1}$ In this context, it is worth emphasizing that researchers are paying more and more attention to Byzantine goldsmiths, i.a. New Research on Late Byzantine Goldsmiths' Works ( $13^{\text {th }}-15^{\text {th }}$ Centuries). Neue Forschungen zur spätbyzantininischen Goldschmiedekunst (13.-15. Jahrhundert), ed. A. BosseLMANn-RuickiIe, Mainz 2019 [= BOO, 13]; EAdEM, Byzantinischer Schmuck des 9. bis frühen 13. Untersuchungen zum metallenen dekorativen Körperschmuck der mittelbyzantinischen Zeit anhand datierter Funde, Wiesbaden 2011 [= SFChB, 28]; Intelligible Beauty. Recent Research on Byzantine Jewellery, ed. C. Entwistle, N. Adams, London 2010. Works related to gold in the context of Late Antique and Byzantine culture are noteworthy as well, e.g. M. GRünBART, Zur Kulturgeschichte des Goldes, [in:] Gold und Blei. Byzantinische Kostbarkeiten aus dem Münsterland, ed. IDEM, Wien 2012, p. 53-66; D. Janes, God and Gold in Late Antiquity, Cambridge 2010 (It ed. Cambridge 1998); S. AWIERINCEw, Złoto $w$ systemie symboli kultury wczesnobizantyjskiej, [in:] IDEM, Na skrzyżowaniu tradycji. Szkice o literaturze i kulturze wczesnobizantyjskiej, trans. et ed. D. UlickA, Warszawa 1988, p. 175-201 (oryg. ed. С.С. Аверинцев, Золото в системе символов ранневизантийской культуры, [in:] Византия, южные славяне и Древняя Русь. Западная Европа. Искусство и культура. Сборник статей в честь В.Н. Лазарева, еd. В.Н. ГрАщенков, Москва 1973, p. 43-52). ${ }^{2}$ The striking lack of more accurate references to gold is particularly evident in studies on Byzantine aesthetics, in which the focus of their authors is mainly the role of the Neoplatonic thought, e.g. В.Н. ЛАЗАРЕВ, История византийской живописи, vol. I, Москва 1947, p. 23-33, 104; П.А. Міхе-

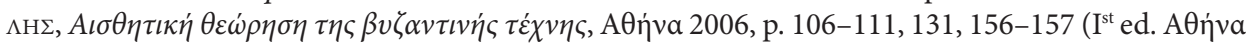
1946); P.A. Michelis, Neo-Platonic Philosophy and Byzantine Art, JAAC 11, 1952, p. 21-45; IDEM, L'esthétique d'Hagia-Sophia, Faenza 1963, p. 44-60 (Ist ed. AӨj́va 1946); G. MAthew, Byzantine Aesthetics, London 1963, p. 13-22, 144; В.В. Бычков, Византийская эстетика. Теоретические проблемы, Москва 1977, раssim; IDEм, Малая история византийской эстетики, Киев 1991, passim.
} 
it is assumed that gold was used primarily because of its symbolic meanings ${ }^{3}$. As a result, the issues pertaining to aesthetics and aesthetic experiences are ignored ${ }^{4}$, although they are the main subject in Byzantine texts. In fact, reading these modern studies, we learn more about contemporary beliefs about Byzantine art than about it itself. The issue of the significance of gold in Byzantine art is unquestionably complex, and for this reason, this article may be only a preliminary outline of the most important questions related to the subject. Selected examples of Byzantine source texts in which their authors referred to gold in a strictly artistic context are the backbone for all considerations. The main thesis statement, which will be proved here, is as follows: gold, as a substantial medium of artistic expression, was used on a large scale primarily for aesthetic reasons. At the outset, it should also be highlighted that the primary sources testify that for over a thousand years of the existence of the Byzantine Empire views on gold did not undergo major shifts, hence these texts do not reflect the changes of Byzantine art. Therefore, it was decided to discuss the topic using the content criterion referring to the aesthetic values that were associated with gold in Byzantium. These values are above all: glow, colour, and splendour.

In the context of the issue of the significance of gold in Byzantine art, ekphraseis ( $\dot{\kappa} \kappa \varphi \rho a ́ \sigma \varepsilon ı \varsigma)$ are the most useful type of texts. They are usually part of larger texts, both poetic and prose ones. Ekphraseis, present in Greek literature from its

\footnotetext{
${ }^{3}$ It seems that Julius Lange was the first who directly indicated that gold backgrounds in medieval paintings can also be understood in symbolic categories. The research direction he outlined was developed and eventually became dominant - also in relation to Byzantine painting; J. LANGE, Et blad af koloritens historie (1893), [in:] Udvalgte Skrifter af Julius Lange, ed. G. Brandes, Р. КøвкE, København 1901, p. 136-156.

${ }^{4}$ This is a general problem related to the study of mediaeval art, because - as Mary Carruthers points out - researchers are used to the question "what does it mean?", and that is why they so easily overlook the problem of aesthetic pleasure of mediaeval people. Her observation can be equally well applied to the study of Byzantine art. However, as Carruthers reasonably indicates, to tackle this kind of topic, our understanding must be changed, because we should move away from nineteenth-century Romantic and twentieth-century Modern categories relevant to art and its perception; M. CARRUTHers, The Experience of Beauty in the Middle Ages, Oxford 2013, passim.

${ }^{5}$ On ekphrasis and its association with art as well i.a. M. SQUire, Ecphrasis. Visual and Verbal Interactions in Ancient Greek and Latin Literature, [in:] Oxford Handbooks Online, 2015, https://doi. org/10.1093/oxfordhb/9780199935390.013.58 [12 V 2020]; R. WeBв, Ekphraseis of Buildings in Byzantium. Theory and Practice, Bsl 69.3, 2011, p. 20-32; EADEM, Ekphrasis, Imagination and Persuasion in Ancient Rhetorical Theory and Practice, Farnham 2009; M. SQuire, Image and Text in Graeco-Roman Antiquity, Cambridge 2015 (I ${ }^{\mathrm{st}}$ ed. Cambridge 2009); S. BARTsCH, J. Elsner, Introduction. Eight Ways of Looking at an Ekphrasis, CP 102.1, 2007, p. I-VI; S. GolDHILL, What Is Ekphrasis for?, CP 102.1, 2007, p. 1-19; J. ElSNER, Introduction. The Genres of Ekphrasis, Ram 31.1-2, 2002, p. 1-18; R. Weвb, Ekphrasis Ancient and Modern. The Invention of a Genre, WI 15.1, 1999, p. 7-18; EADEM, The Aesthetics of Sacred Space. Narrative, Metaphor, and Motion in "Ekphraseis" of Church Buildings, DOP 53, 1999, p. 59-74; L. JAmes, R. WeBB, "To Understand Ultimate Things and Enter Secret Places". Ekphrasis and Art in Byzantium, ArH 14.1, 1991, p. 1-17.
} 
very beginnings, became extremely popular in late antiquity because they allowed both the use of a variety of stylistic devices and the choice of attractive subjects ${ }^{6}$. Byzantine authors carried on taste for them. Nicholas of Myra (also known as Nicholas Rhetor, ca. 410 - ca. 490) defined the ekphrasis in his Progymnasmata

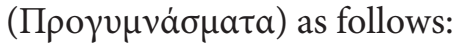

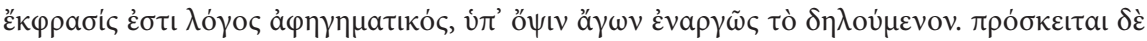

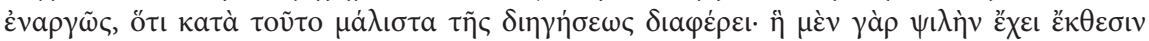

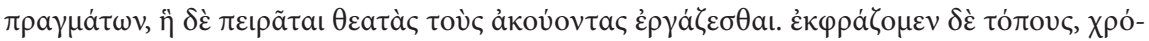

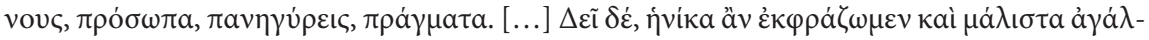

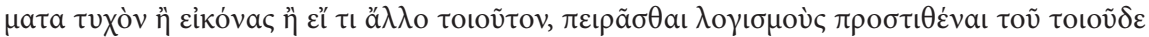

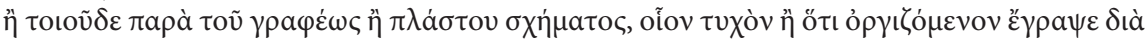

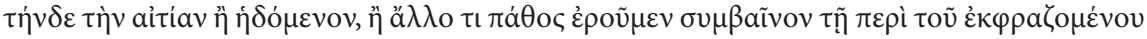

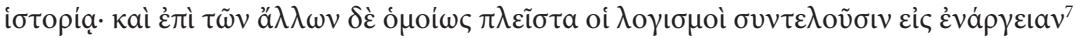

[...] ecphrasis (ekphrasis) is descriptive speech, bringing what is described clearly (enargôs) before the eyes. "Clearly" is added because in this way it most differs from narration; the latter gives a plain exposition of actions, the former tries to make the hearers into spectators. We compose ecphrases of places, times, persons, festivals, things done [...] Whenever we compose ecphrases, and especially descriptions of statues or pictures or anything of that sort, we should try to add an account of this or that impression made by the painter or by the molded form; for example, that he painted the figure as angry for this reason, or as pleased; or we shall mention some other emotion as occurring because of the history of what is being described. Similarly in other cases also, explanations contribute to vividness ${ }^{8}$.

Therefore, the key to a brilliant ekphrasis is to bring the described things - including works of art - or events clearly ( $\dot{\varepsilon} v \alpha \rho \tilde{\omega} \tilde{c}$; so also $\varphi \alpha v \varepsilon \rho \tilde{\omega} \varsigma$, i.e.: plainly, openly, manifestly, evidently ${ }^{9}$ ) before the eyes of an audience ( $\dot{v} \pi^{\prime}$ ó $\psi \iota \nu$ á $\gamma \omega \nu \dot{\varepsilon} v a \rho-$ $\gamma \tilde{\omega} \varsigma$ tò $\delta \eta \lambda o v j \mu \varepsilon v o v)$, since this is the only way that listeners can become spec-

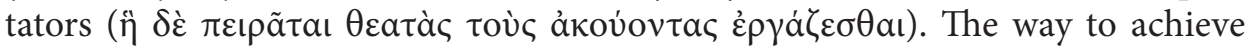
this desirable feature was, in particular, a thoroughgoing description which was

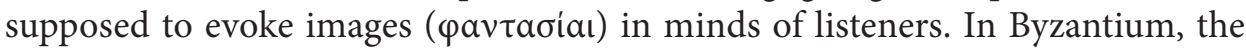
creation of ekphraseis - as in antiquity - was a part of the elementary stage of

\footnotetext{
${ }^{6}$ M. Roberts, The Jeweled Style. Poetry and Poetics in Late Antiquity, Ithaca 1989, p. 39-65.

${ }^{7}$ Nicolai progymnasmata, 68-69, ed. J. FeLten, Leipzig 1913 [= RG, 11; BSGR].

${ }^{8}$ Progymnasmata. Greek Textbooks of Prose Composition and Rhetoric, 68-69, trans., praef. G.A. KENNEDY, Atlanta 2003 [= WGRW, 10], p. 166-167.

${ }^{9}$ Iohannis Zonarae lexicon ex tribus codicibus manuscriptis, 753.15, vol. I, ed. J.A.H. TittmanN,

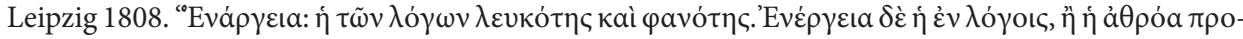

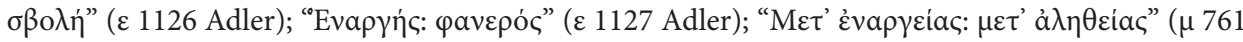
Adler); The Suda on Line, http://www.stoa.org/sol/ [25 V 2020]. Cf. Etymologicum Gudianum, $\varepsilon$ 467, vol. I, ed. E.L. DE Stefani, Leipzig 1909 [= BSGR]; Etymologicum magnum, 337, ed. T. Gaisford, Oxford 1848; Etymologicum Symeonis (T-E), ع 391, ed. D. BALDI, Turnhout 2013 [= CC.SG, 79]. On

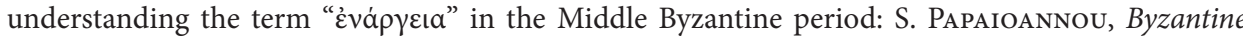
Enargeia and Theories of Representation, Bsl 69, 2011, p. 48-60.
} 
the rhetorical education during which the late antique textbooks with the preliminary exercises (i.e. $\pi \rho \gamma v \mu \nu \alpha \dot{\sigma} \sigma \alpha \tau \alpha$, praeexercitamina) were employed. These works, as well as other texts on the theory of rhetoric, were commented and summarized by Byzantine authors. Some of them, e.g. John Geometres (ca. 935 - ca. 1000) ${ }^{10}$, Nikephoros Basilakes (ca. 1115 - after 1182) ${ }^{11}$, and George Pachymeres $(1242-\text { ca. } 1310)^{12}$, prepared their own ones as well ${ }^{13}$.

Ekphraseis are often very significant sources for Byzantine art studies. Byzantine authors of such descriptions used to write not so much about the details of the appearance of a given image or building, but mainly about the reactions of the audience. In fact, the most crucial task was not to refer to a real, specific work of art, but to evoke in a listener - by referring to the collective cultural memory - the sense that such piece of art might exist. Thus, ekphraseis were, above all, a kind of intellectual play of a given author with his listeners. Hence, they may say a lot about the culture in which they were created. These texts may be helpful in comprehending Byzantine notions on art as well, because they indicate to us what Byzantines found significant. On their basis, therefore, it is possible to draw conclusions regarding the perception of works of art, as well as prized aesthetic

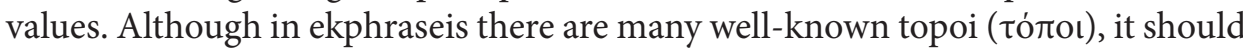
be emphasized that they were not only ornaments indicating the author's erudition, but also elements carrying specific and legible content. The use of topoi that would no longer be understandable would interfere with communication, and as a result, an ekphrasis would not bring the subject described before the eyes with visual vividness ${ }^{14}$. The authors, however, had a wide range of rhetorical devices to

\footnotetext{
${ }^{10}$ The Progymnasmata of Ioannes Geometres, ed. A.R. Littlewood, Amsterdam 1972.

${ }^{11}$ Niceforo Basilace, Progimnasmi e monodie, ed. A. Pignani, Napoli 1983 [= BNN, 10], p. 71-232; The Rhetorical Exercises of Nikephoros Basilakes. "Progymnasmata" from Twelfth-Century Byzantium, ed., trans. J. Beneker, C.A. Gibson, Cambridge Mass.-London 2016 [= DOML, 43].

${ }^{12}$ Rhetores Graeci, 551-596, vol. I, ed. C. Walz, Stuttgart 1832.

${ }^{13}$ H. Сiсноска, Teoria retoryki bizantyńskiej, Warszawa 1994, p. 86-125; R. Betancourt, Sight, Touch, and Imagination in Byzantium, Cambridge 2018, p. 203-222.

${ }^{14}$ L. James, R. WebB, "To Understand..., p. 3, 9, 14. Cf. C. Mango, Antique Statuary and the Byzantine Beholder, DOP 17, 1963, p. 64-70; H. Maguire, Truth and Convention in Byzantine Descriptions of Works of Art, DOP 28, 1974, p. 113-140; J. OnIANs, Abstraction and Imagination in Late Antiquity, ArH 3, 1980, p. 1-24; H. Maguire, Art and Eloquence in Byzantium, Princeton 1981, p. 22-52; L. Brubaker, Perception and Conception. Art, Theory and Culture in Ninth-Century Byzantium, WI 5, 1989, p. 19-32; A. EAstmond, An Intentional Error? Imperial Art and "Mis"-Interpretation under Andronikos I Komnenos, ArtB 76, 1994, p. 502-510; H. Maguire, Originality in Byzantine Art, [in:] Originality in Byzantine Literature, Art and Music. A Collection of Essays, ed. A.R. LitTlewood, Oxford 1995 [= OMon, 50], p. 101-114; R.S. Nelson, To Say and to See. Ekphrasis and Vision in Byzantium, [in:] Visuality before and beyond the Renaissance. Seeing as Others Saw, ed. IDEM, Cambridge 2000, p. 143-168; H. Maguire, Art and Text, [in:] The Oxford Handbook of Byzantine Studies, ed. E. Jeffreys, J. Haldon, R. CoRmaCK, Oxford 2008, p. 721-730; IDEM, The Realities of Ekphrasis, Bsl 69.3, 2011, p. 7-19; N. Zarras, A Gem of Artistic Ekphrasis. Nicholas Mesarites' Description of the Mosaics in the Church of the Holy Apostles at Constantinople, [in:] Byzantium, 1180-1204. 'The Sad
} 
achieve this required effect in their texts. In the Description of the all-praiseworthy

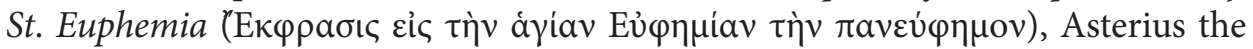
bishop of Amasea (ca. 350 - ca. 410) wrote about these media of expression, using

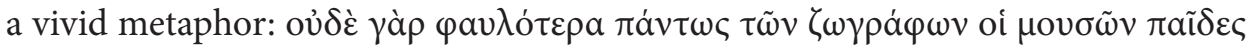

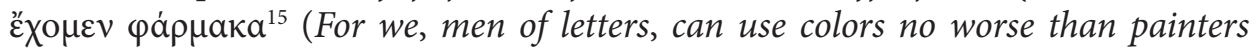
do $)^{16}$. Thus, Henry Maguire pertinently points out that:

A closer reading of the Byzantine rhetorical writers reveals that they were extremely sensitive to artistic styles and to their meanings, whether those styles were, in present-day terms, classicizing and naturalistic on the one hand, or unclassical and schematic on the other. The difference between Byzantine and modern art criticism lies not in perception but in language. The Byzantines were not blind, but they were using a language completely different from those of twentieth-century critics, and for this reason their statements have been misunderstood $^{17}$.

Hence, despite some conventionality and a specific language, ekphraseis may be substantial primary sources, also when it comes to the issue of the significance of gold in Byzantine art.

According to Byzantine texts, beauty was the main idea with which gold was associated. Plotinus (ca. 204 - ca. 270) was the first who constituted the theoreti-

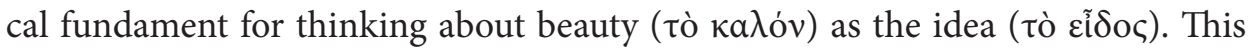
philosopher pointed out that beauty is the idea manifested in different ways. Then, the presence of the idea is vital ${ }^{18}$. In this way, therefore, widespread observations

Quarter of a Century'?, ed. A. Simpson, Athens 2015, p. 261-282; P.Ł. Grotowsкi, O sztuce cytowania - chresis jako źródło w badaniach nad recepcja idei obrazu w Bizancjum, [in:] Hypomnemata Byzantina. Prace ofiarowane Maciejowi Salamonowi, ed. J. Bonarek, S. Turlej, Piotrków Trybunalski 2017, p. 56-57; H. Maguire, The Asymmetry of Text and Image in Byzantium, PM.RELLMA 38, 2017, https://doi.org/10.4000/peme.12218 [12 V 2020]; M. SMorąG RóżyCKA, Miejsce ekfrazy $w$ bizantynistycznej historiografii artystycznej, VP 70, 2018, p. 471-484.

${ }^{15}$ Euphémie de Chalcédoine. Légendes byzantines, 1.14-15, ed. F. Halkin, Bruxelles 1965 [= SHa, 41]. ${ }^{16}$ C. Mango, The Art of the Byzantine Empire 312-1453, Toronto-Buffalo-London 2013 [= Medieval Academy Reprints for Teaching, 16], p. 38 (Ist ed. Englewood Cliffs 1972).

${ }^{17}$ H. Maguire, Originality..., p. 102.

${ }^{18}$ Plotini opera, vol. I, Porphyrii vita Plotini et enneades I-III, e.g. 1.6.1.1-3; 1.6.1.17-36; 1.6.2.1-6; 1.6.2.11-28, ed. P. Henry, H.-R. Schwyzer, Leiden 1951 [= ML.SPh, 33]. In this context, it is also worth pointing to Michael Psellos' short commentary:

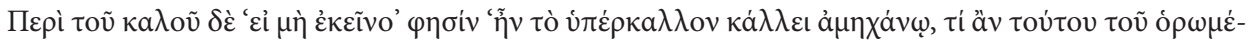

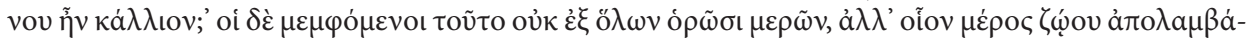

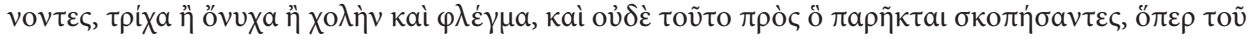

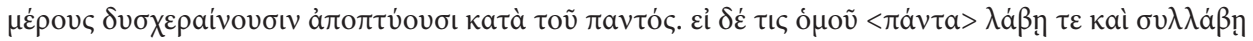

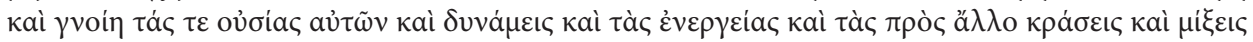

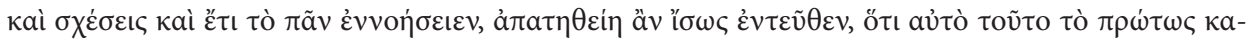

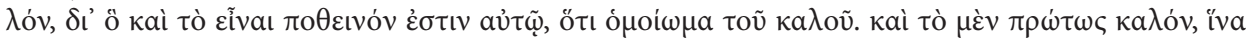

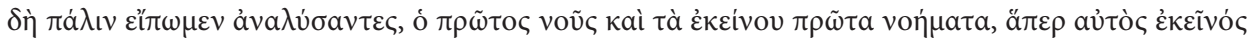

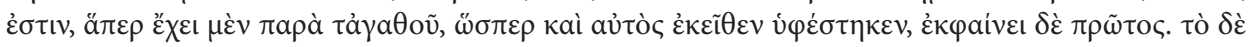


- Plotinus, after all, did not have to order people to recognize light, gold, or stars as beautiful - gained a weighty philosophical foundation. As for the late antique and Byzantine plastic arts themselves, it is difficult to talk about the direct impact of the Plotinus' thoughts on their shape ${ }^{19}$. His aesthetic considerations, however, played an important role in Byzantine culture, because they were accepted by the Church Fathers thanks to whom the Plotinus' understanding of the perceptible beauty was consolidated ${ }^{20}$.

For Byzantine authors, the beauty of gold essentially meant its glow - so it was directly related to light - as well its colour. Both attributes were positively perceived in antiquity, but it seems that they were particularly appreciated in late antiquity, and on this account, it can be said that at that time there was formed an aesthetic thought in which variegation (

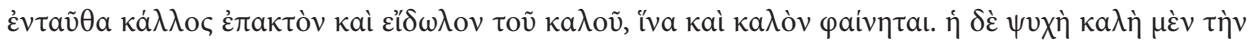

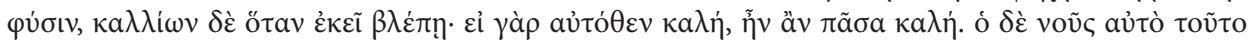

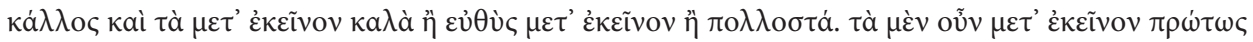

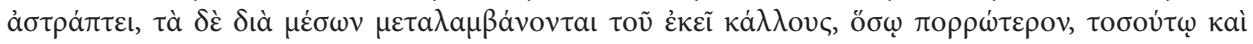

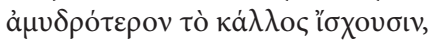

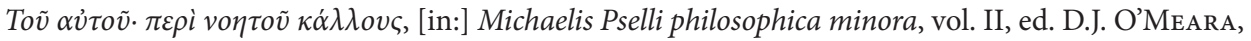
Leipzig 1989 [= BSGR], p. 117.

${ }^{19}$ Cf. e.g.: A. Grabar, Plotin et les origines de l'esthétique médiévale, [in:] IDEM, Les origines de l'esthétique médiévale, ed. G. Dagron, Paris 1992, p. 29-87 (oryg. ed. CAr 1, 1945, p. 15-34); P.A. Michelis, Neo-Platonic Philosophy..., p. 21-45; H.P. L'Orange, Art Forms and Civic Life in the Late Roman Empire, Princeton 1965, p. 19-33 (It ed. Oslo 1958); G. Mathew, Byzantine ..., p. 2-22; G.M. GurtLer, Plotinus and Byzantine Aesthetics, MSch 66.4, 1989, p. 275-284. See as well: S. MarIEv, Introduction. Byzantine Aesthetics, [in:] Aesthetics and Theurgy in Byzantium, ed. S. Mariev, W.-M. STOCK, BerlinBoston 2013 [= BArchiv, 25], p. 2-11; J. Haldane, Medieval Aesthetics, [in:] The Routledge Companion to Aesthetics, ed. B. Gaut, D. McIver Lopes, London 2013 [= RPhC], p. 26-28 ( ${ }^{\text {st }}$ ed. London 2000). ${ }^{20}$ E.g.:

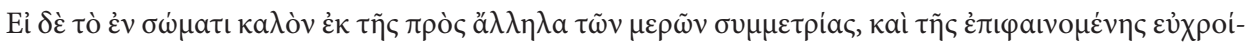

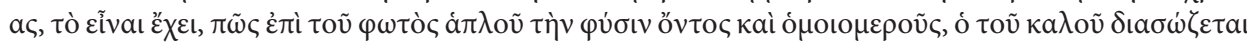

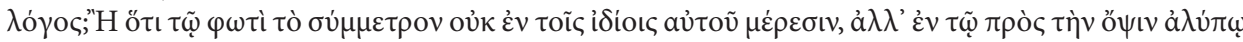

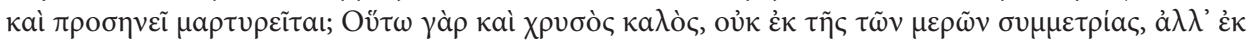

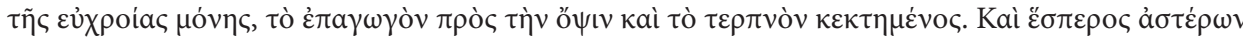

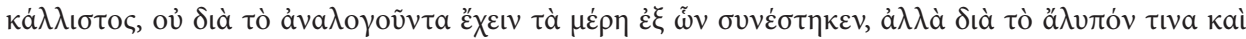

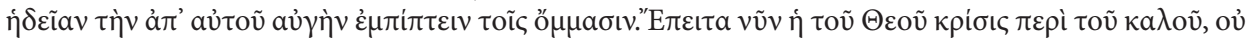

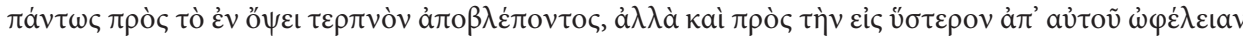

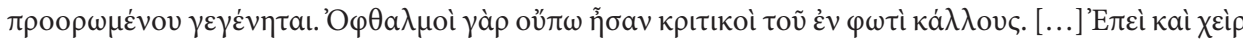

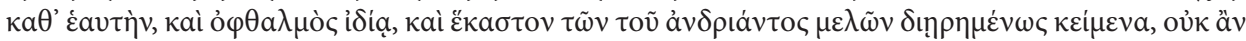

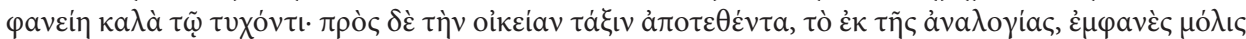

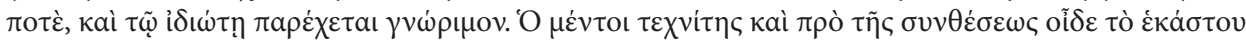

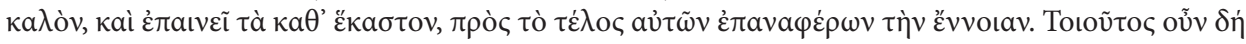

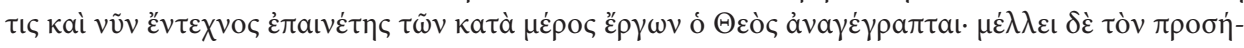

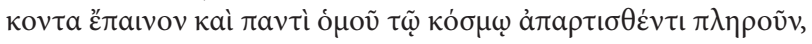

Basile de CÉsarée, Homélies sur l'hexaéméron, 2.7.39-55; 3.10.8-18, ed. S. Giet, Paris 1968 [= SC, 26 bis]. 
It was related to colours and visual effects on shimmering surfaces of various materials, such as gold, precious stones, marbles, and fabrics. This kind of aesthetic inclinations was then adopted in Byzantium where they did not lose its relevance until the end of the empire's existence, as evidenced by numerous texts and works of art.

In the context of the late antique aesthetics, Michael Roberts coined the evocative term "jeweled style" to illustrate concisely a change in taste in the contemporary poetry, whereby he refers chiefly to the Latin literature. According to Roberts, the classical poetics was then rejected in favour of a new one, in which instead of the simplicity and unity of composition, the variety (varietas, variatio) was particularly delighted and due to it even a simple topic could become interesting and decorative (ornatus). Therefore, repetition was avoided, and authors used to use synonyms and circumlocutions to prevent monotony. The literature created in this way was supposed to be like a shimmering gem (gemma) that attracts attention with its glitter (lumen) and colour (color $)^{21}$. Although it is difficult to agree with all the detailed considerations of the researcher, who sometimes compares literature with painting too easily, his term "jeweled style", in the context of art understood simply as a predilection for sophisticated, multi-coloured and shiny materials, quite aptly describes the late-antique and Byzantine aesthetics ${ }^{22}$.

Referring directly to Byzantine primary sources, it should be stressed that gold in ekphraseis, full of admiration for visible beauty, appears as one of the quintessential precious materials, and this is the most characteristic feature: gold does not have a unique, special position among them, since marbles, precious stones, and expensive fabrics are not perceived as less valued. Let's study some specific examples. Describing the church of the Holy Wisdom in Constantinople, Paulus Silentiarius (died ca. 575-580) wrote:

\footnotetext{
${ }^{21}$ M. RoberTs, The Jeweled..., p. 39- 65.

${ }^{22}$ Cf.: P. Cox Miller, "The Little Blue Flower Is Red". Relics and the Poetizing of the Body, JECS 8.2, 2000, p. 213-236; T.K. Thomas, The Medium Matters. Reading the Remains of a Late Antique Textile, [in:] Reading Medieval Images. The Art Historian and the Object, ed. E. SeArs, T.K. Thomas, Ann Arbor 2002, p. 39-49; L. JAMEs, Color and Meaning in Byzantium, JECS 11.2, 2003, p. 223-233; E.S. Bolman, Late Antique Aesthetics, Chromophobia and the Red Monastery, Sohag, Egypt, ECA 3, 2006, p. 18-22; J. Elsner, Late Antique Art. The Problem of the Concept and the Cumulative Aesthetic, [in:] Approaching Late Antiquity. The Transformation from Early to Late Empire, ed. S. SwAIN, M. Edwards, Oxford 2006, p. 271-309; P. Cox Miller, The Corporeal Imagination. Signifying the Holy in Late Ancient Christianity, Philadelphia 2009, p. 17, 18, 43-44; E.S. Bolman, Painted Skins. The Illusions and Realities of Architectural Polychromy, Sinai and Egypt, [in:] Approaching the Holy Mountain. Art and Liturgy at St Catherine's Monastery in the Sinai, ed. S.E.J. Gerstel, R.S. Nelson, Turnhout 2010 [= CMu, 11], p. 119-140; B.V. Pentcheva, The Sensual Icon. Space, Ritual, and the Senses in Byzantium, University Park 2010, p. 139-149; N. Schibille, Hagia Sophia and the Byzantine Aesthetic Experience, Farnham 2014, p. 97-99, 108; B.V. Pentcheva, Hagia Sophia, Sound, Space, and Spirit in Byzantium, University Park 2017, p. 121-149; V. Ivanovici, Divine Light through Earthly Colours. Mediating Perception in Late Antique Churches, [in:] Colour and Light in Ancient and Medieval Art, ed. C.N. Duckworth, A.E. Sassin, New York-London 2018, p. 81-91.
} 


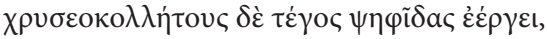

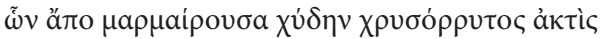

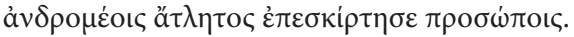

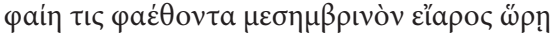

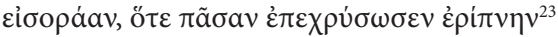

The roof is compacted of gilded tesserae from which a glittering stream of golden rays pours abundantly and strikes men's eyes with irresistible force. It is as if one were gazing at the midday sun in spring, when he gilds each mountain top ${ }^{24}$.

Here, the poet drew attention not only to the golden mosaic cubes ( $\chi \rho \vee \sigma \varepsilon о \kappa о \lambda-$ $\lambda$ nंtov $\psi \eta \varphi \tilde{i} \delta \alpha \varsigma)$ covering the vaulted parts but also emphasized that the rays of

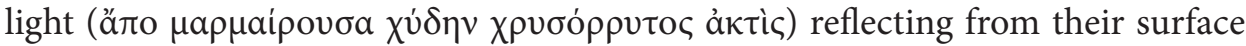

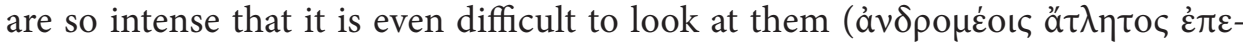

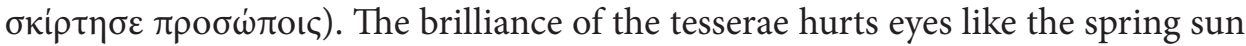

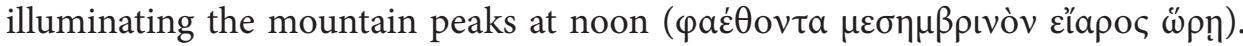
It should be noted that the colour of the sun's rays, both in the church and out-

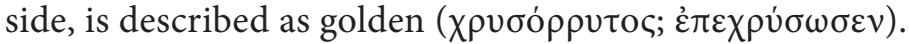

It is worth adding that Silentarius in some very poetic lines contained quite specific content because authors frequently used to stop on more general statements. For example, Procopius of Caesarea (ca. 500 - ca. 565) wrote on the same

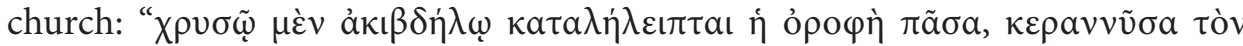

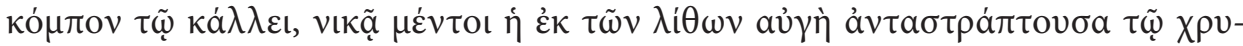
$\sigma \tilde{\omega}{ }^{\prime \prime 25}$ (The whole ceiling is overlaid with pure gold, which adds glory to the beauty, yet the light reflected from the stones prevails, shining out in rivalry with the gold $)^{26}$. Thus he did not specify that the vaults were decorated with gold tesserae but he admitted that this part of the building is beautiful and resplendent. Notwithstanding this opinion, Procopius found that the glow of marbles ( $\dot{\eta} \dot{\varepsilon} \kappa \tau \tilde{\omega} v \lambda i \theta \omega \nu$ aủ $\gamma \grave{\eta}$

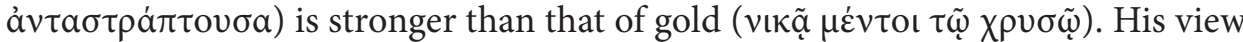
may seem somewhat surprising, but a little further we read as well: "ó $\delta \dot{\varepsilon} \chi \alpha \lambda \kappa o ̀ \varsigma$

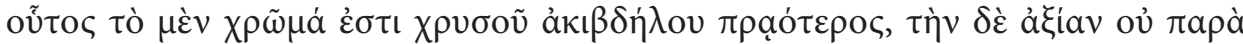

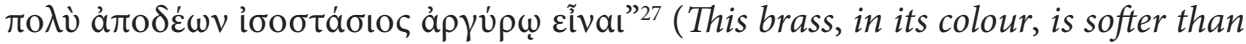
pure gold, and its value is not much less than that of an equal weight of silver $)^{28}$. It is

\footnotetext{
${ }^{23}$ Paulus Silentiarius, Descriptio Sanctae Sophiae, 668-672, [in:] Paulus Silentiarius, Descriptio Sanctae Sophiae, Descriptio Ambonis, ed. C. De Stefani, Berlin-New York 2010 [= BSGR] (cetera: Paulus Silentiarius).

${ }^{24}$ C. Mango, The Art of the Byzantine..., p. 86.

${ }^{25}$ Procopii Caesarensis opera omnia. De aedificiis, I, 1, 54, vol. IV, ed. J. Haury, rec. G. WirTh, Leipzig 1964 [= BSGR] (cetera: ProcopIUs).

${ }^{26}$ Procopius, On Buildings, I, 1, 54, trans. H.B. Dewing, G. Downey, Cambridge Mass.-London 1954 [= LCL, 343].

${ }^{27}$ Procopius, I, 2, 4.

${ }^{28}$ Procopius, On Buildings..., I, 2, 4.
} 
interesting that both Procopius and Silentarius noticed some weaknesses of gold, especially since their feelings are opposite - although they both described the same dome - because for the first author gold glitters less than marbles, and its colour is less delicate than that of copper, and for the second one, the glow of golden mosaic cubes is too dazzling.

Other writers also used to point to the special visual effects associated with golden surfaces, both earlier such as Eusebius of Caesarea (ca. 260 - ca. 339) ${ }^{29}$ and later ones. Of the latter, it is especially worth paying attention to the text from around the mid-twelfth century whose author is Michael protecdicus ( $\pi \rho \omega \tau \varepsilon \dot{\varepsilon} \delta \delta_{-}-$ $\kappa о \varsigma)^{30}$ of the church of Thessalonica and later deacon of the church of the Holy Wisdom in Constantinople. His composition is on folios $123 \mathrm{r}-124 \mathrm{v}$ of the Escorial codex Y-II-10 (Real Biblioteca del Monasterio de San Lorenzo de El Escorial) and it is the ekphrasis of the Holy Wisdom church written for the annual celebration of the inauguration of the church. This text consists of 232 lines - unfortunately, it is incomplete now - and refers to the architectural form of the church and its symbolic interpretation as well ${ }^{31}$. What is more, the author remarked on the building's decoration, and, at the very beginning, he emphasized that the

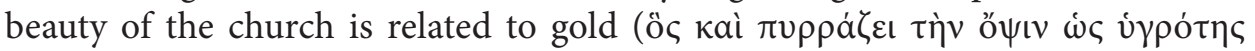

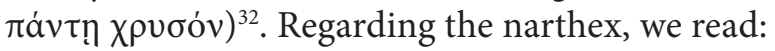

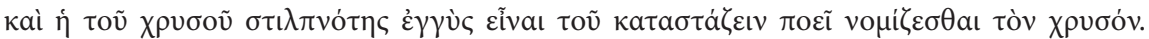

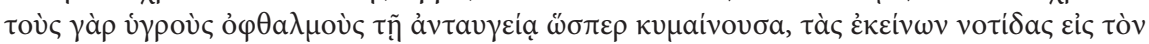

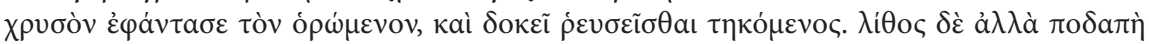

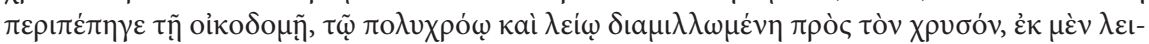

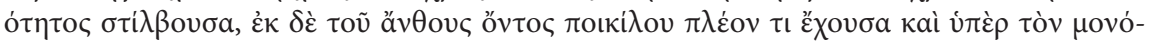

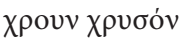

[...] and the brightness of the gold almost makes the gold appear to drip down; for by its refulgence making waves to arise, as it were, in eyes that are moist, it causes their moisture to appear in the gold which is seen, and it seems to be flowing in a molten stream. But what

${ }^{29}$ E.g. his description of the church of the Holy Apostles in Constantinople:

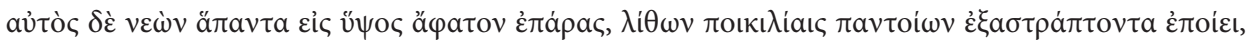

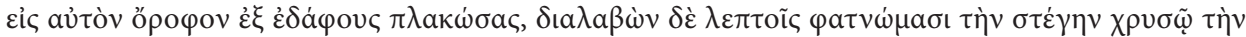

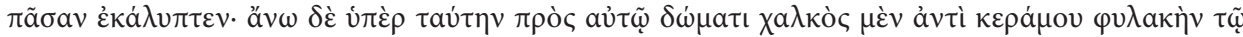

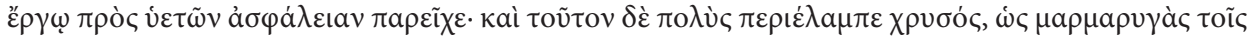

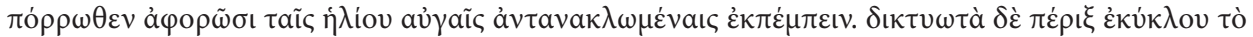

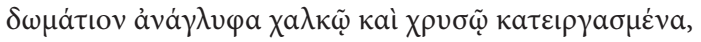

Eusebius Werke, vol. I.1, Über das Leben des Kaisers Konstantin, 4.58-4.59, ed. F. WinkeLmann, Berlin 1975 [= GCS].

${ }^{30}$ Glossarium ad scriptores mediae et infimae latinitatis, vol. VI, ed. C. DU Fresne DU CANGE, Niort 1883-1887, 541a (s.v. Protecdicus).

${ }^{31}$ C. Mango, J. PArker, A Twelfth-Century Description of St. Sophia, DOP 14, 1960, p. 233-235.

${ }^{32}$ This text was edited and translated by Cyril Mango and John Parker. They also provided it with an introduction and commentary; C. Mango, J. PArker, A Twelfth-Century..., 1.12-13, p. 235. 
manner of stonework is this that fastened around the building, striving with its variegated coloring and smoothness against gold, shining because of its smoothness and, because of its diversified bloom having something that surpasses even the gold, which is of one color? ${ }^{33}$.

To Michael, gold - because of its intense gloss - seems to be flowing down the

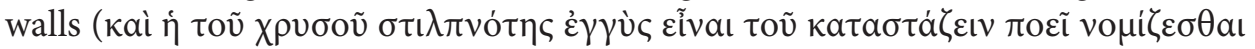

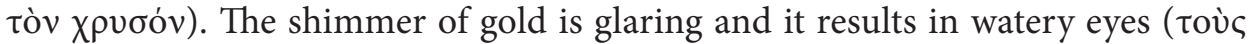

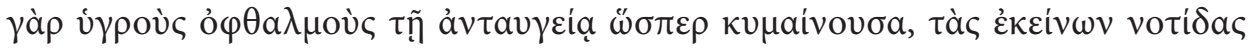

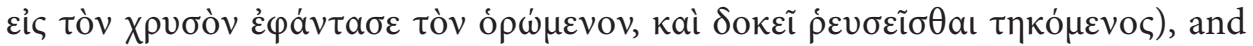
the stones, due to their variegation of colours, resemble flowers in bloom ( $\dot{\varepsilon} \kappa \delta \dot{\varepsilon}$

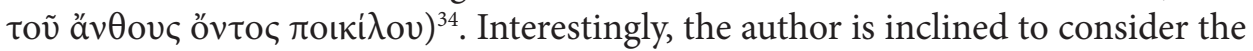
multi-coloured revetments as more beautiful than gold which is, after all, of one

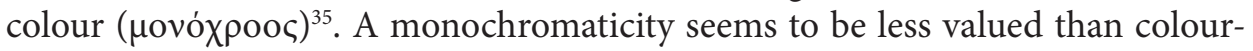

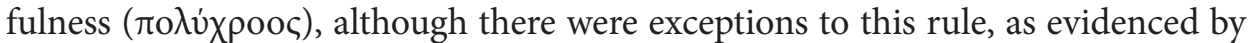
the description of the floor in one of the homilies of Leo VI the Wise (886-912) ${ }^{36}$.

${ }^{33}$ C. Mango, J. Parker, A Twelfth-Century..., 3.67-79, p. 237 (There are the Greek text and the English translation).

${ }^{34}$ This kind of comparison of multi-coloured stones to blooming flowers is quite common in Byz-

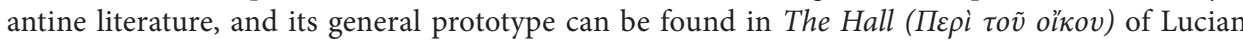
of Samosata. However, he compared frescoes, not marbles, to a flourishing meadow; LuCian, The Hall, 9, [in:] Lucian, Phalaris. Hippias or The Bath. Dionysus. Heracles. Amber or The Swans. The Fly. Nigrinus. Demonax. The Hall. My Native Land. Octogenarians. A True Story. Slander. The Consonants at Law. The Carousal (Symposium) or The Lapiths, vol. I, ed. A.M. Harmon, Cambridge Mass. 1913 [= LCL, 14]. This motif, as it seems, has been referred to marble revetments and floors since the $6^{\text {th }}$ century; H. Maguire, Nectar \& Illusion. Nature in Byzantine Art and Literature, Oxford 2016 [= OSHC], p. 121-122 ( $\mathrm{I}^{\text {st }}$ ed. Oxford 2012). In this early period, we find it, among others, in Procopius (Procopius, 1.1.59-60), as well as in the carved inscription of the church of St. Polyeuctus in Constantinople (Anthologia Graeca, 1.10.60-69, vol. I, ed. Н. Вескву, München 1965). This comparison turned out to be extremely enduring, because it was often used for the next centuries, until the end of Byzantium, since the beauty of various stones decorating interiors was constantly emphasized and glorified. See as well: Gregorius Nyssenus, De sancto Theodoro, [in:] PG, vol. XLVI, col. 737.48-740.6; Choricii Gazaei opera, 2.2.40, ed. R. Foerster, E. Richtsteig, Leipzig 1929 [= BSGR] (cetera: CHORICIUs).

${ }^{35}$ Reading Byzantine primary sources, one could often find that the most wonderful visual effects are associated not with gold but with multi-coloured stones, both marbles, and gems, to which the former ones are regularly compared. In the context of stone revetments, the example of the poetic ekphrasis of the Constantinopolitan church of the Holy Wisdom of Silentiarius is significant. His description of the church's marbles is extensive and very detailed, because it does not boil down to the general highlighting of their diverse colours and extraordinary gloss. Therefore, almost all the stones mentioned in the poem can be accurately recognized and assigned to individual places of the church; N. Schibille, Hagia Sophia..., p. 97-109, 241-243. It should be clearly emphasized that the Silentiarius' ekphrasis is a unique combination of elaborate poetry with a large dose of specific information, which was quoted in a very erudite form; Paulus Silentiarius, 617-646, 664-667.

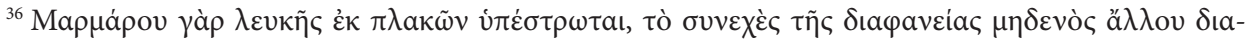

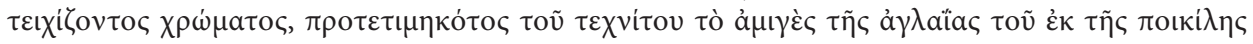

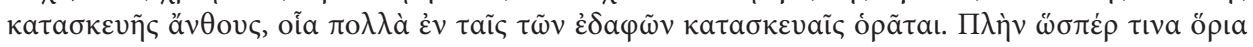


The author underlined there that the pavement made of white slabs is beautiful because of its one colour, and it is a pure splendour for him. In general, the combination of materials of different colours providing stunning visual effects was valued more than simplicity praised by Leo.

In the context of extraordinary impressions, the $X$ Homily of Photius I of Constantinople $(858-867,877-886)$ immediately comes to mind. The patriarch prepared it on the occasion of the inauguration of the church of the Virgin of the Pharos at the Great Palace of Constantinople. This event took place in 864 during the reign of Michael III (842-867) ${ }^{37}$ :

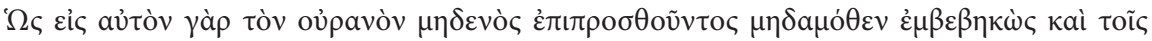

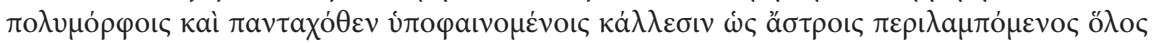

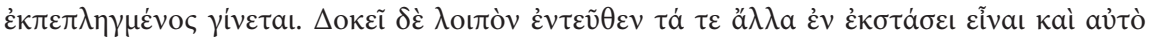

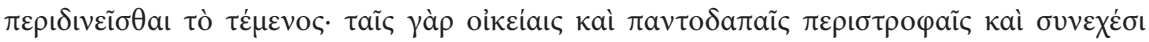

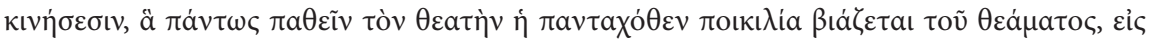

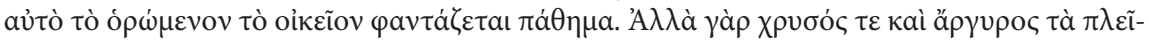

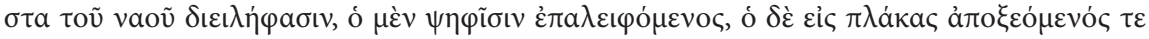

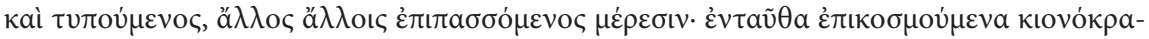

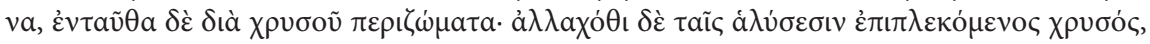

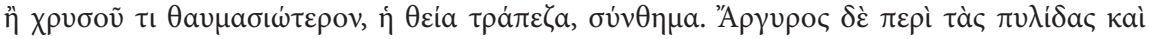

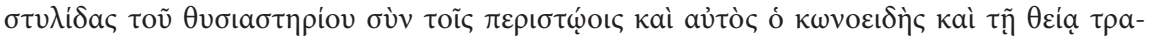

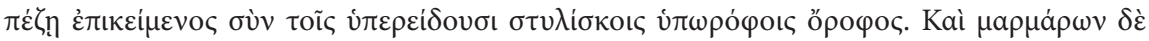

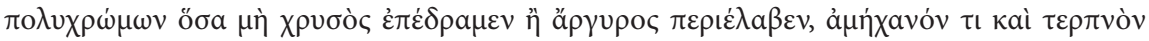

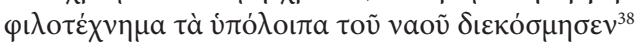

It is as if one had entered heaven itself with no one barring the way from any side, and was illuminated by the beauty in all forms shining all around like so many stars, so is one utterly amazed. Thenceforth it seems that everything is in ecstatic motion, and the church itself is circling around. For the spectator, through his whirling about in all directions and being constantly astir, which he is forced to experience by the variegated spectacle on all sides, imagines that his personal own is transferred to the object. Gold and silver cover the greater part of the church, the one smeared on tesserae, the other cut out and fashioned into plaques, or otherwise applied to other parts. Over here are capitals adorned with gold, over there are golden cornices. Elsewhere gold is twined into chains, but more wonderful than gold is the composition of the holy table. The little doors and columns of the sanctuary together with the peristyle are covered with silver; so also is the conical roof set over the holy table with the

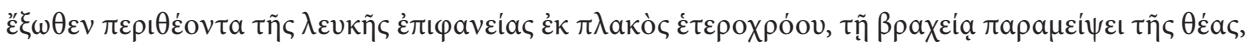

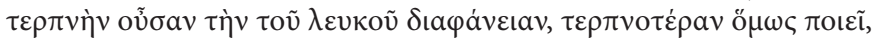

Leonis VI Sapientis Imperatoris Byzantini Homiliae, 31.54-61, ed. T. Antonopoulou, Turnhout 2008 [= CC.SG 63] (cetera: LEO VI).

${ }^{37}$ R.J.H. Jenkins, C. Mango, The Date and Significance of the Tenth Homily of Photius, DOP 9/10, 1956, p. 125-140; A. RóżyCKA BRYzeK, Focjusz, patriarcha Konstantynopola, „Homilia X”, Z 466.3, 1994, p. 57.

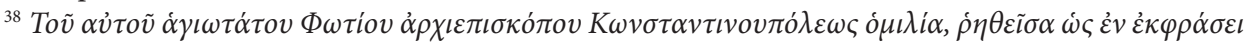

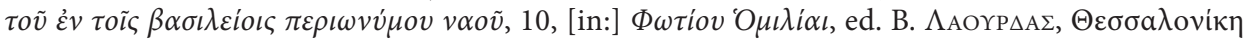
1959 [= ЕП ЕМ ПП, 12] (cetera: Рнотіus), p. 101.18-31 - 102.1-5. 
little pillars and canopy that support it. The rest of the church, as much of it as gold has not overspread or silver covered, is adorned with many-hued marble, a surpassingly fair work ${ }^{39}$.

In his solemn speech, Photius used well-known and much earlier developed schemes for describing the church's interior, and his ekphrasis is, in fact, rather general, thus it could be applied easily as a description of another church. As for gold, he mentioned that it is in the mosaic cubes (ó $\mu \dot{\varepsilon} \nu \psi \eta \varphi \tilde{\imath} \sigma \nu \dot{\varepsilon} \pi \alpha \lambda \varepsilon ı \varphi$ ó $\mu \varepsilon v o \varsigma$ )

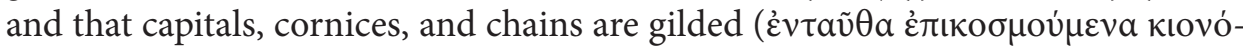

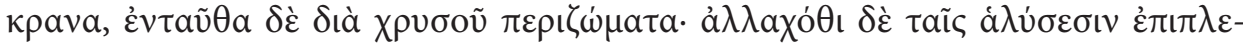
кó $\mu \varepsilon v о \varsigma \chi \chi \nu v \sigma o ́ \varsigma)$. The author, however, emphasized that the altar with the silver

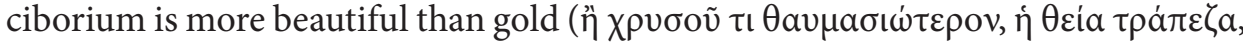
$\sigma \dot{v} v \theta \eta \mu \alpha)$. It seems that in this way Photius rather indicates that the sanctuary is the most important part of the church than comments on aesthetics. The patriarch certainly succeeded in creating the vision of the splendour of the new foundation:

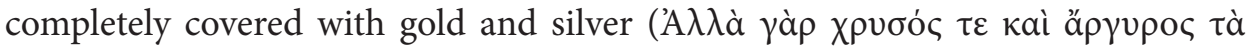

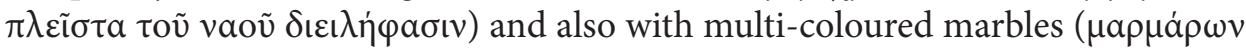
$\delta \grave{\varepsilon} \pi \mathrm{o} \lambda \nu \chi \rho \omega \mu \omega v)$. It is worth adding that the homily was given in situ, which also allowed for less scrupulous explanations. Anyway, the Photius himself justified his approach with rhetorical emphasis:

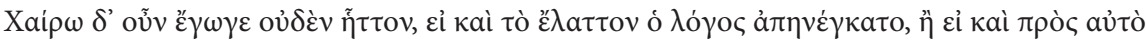

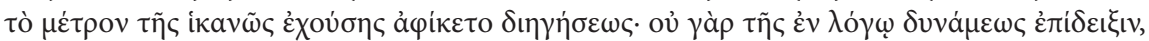

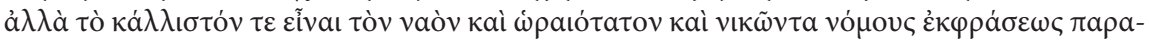

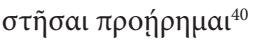

Yet, even if my speech has fallen below the mark, I am not any the less content than if it had risen to the level of an adequate description. For my purpose was not to make an exhibition of eloquence but to show that the church is most excellent and beautiful and that it defeats the canons of an ekphrasis ${ }^{41}$.

\footnotetext{
${ }^{39}$ The Homilies of Photius, Patriarch of Constantinople, 10.5, trans., praef. C. Mango, Cambridge Mass. 1958 [= DOS, 3], p. 186-187.

${ }^{40}$ Photius, 10, p. 103.23-27. In Homily XVII, Photius also emphasized the power of sight - a sense that surpasses hearing (Рнотіus, 17, p. 170.28-33):

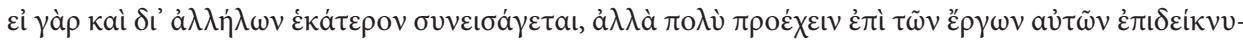

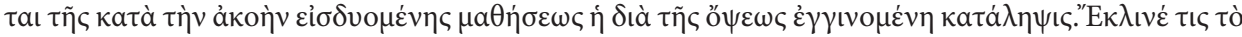

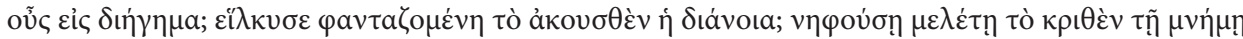

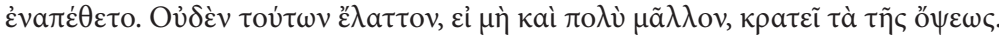

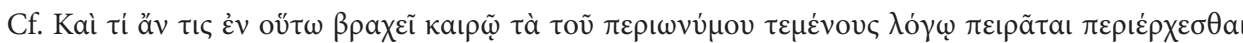

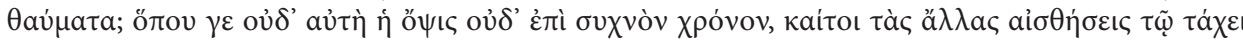

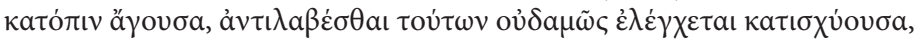

Photius, 10, p. 103.19-23. On the theory of perception of Photius: R. Betancourt, Sight..., p. 109-195.

${ }^{41}$ The Homilies of Photius..., 10.7, p. 189. 
The $X$ Homily of Photius, which passages were cited above, was formerly con-

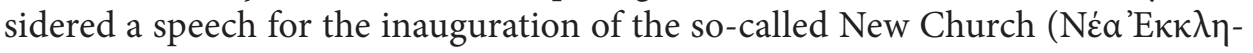
oia) funded by Basil I the Macedonian (867-886). Cyril Mango proves, however, that the text refers to the church of the Virgin of the Pharos ${ }^{42}$. The description

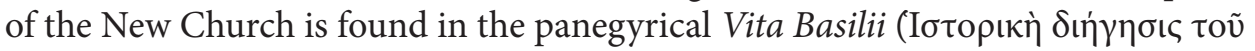

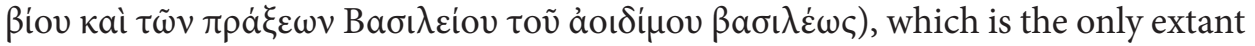
secular biography in Byzantine literature. The emperor was presented there not only as a brave warrior, but also as a generous founder, who raised many churches from ruin and also built numerous new ones ${ }^{43}$.

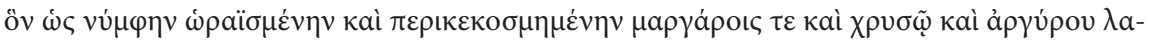

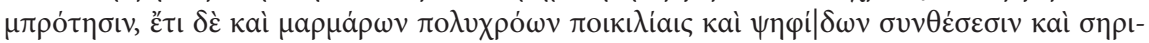

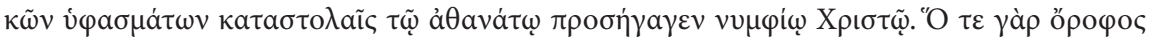

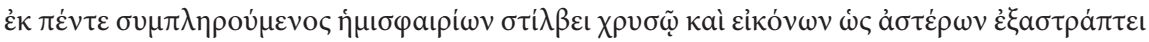

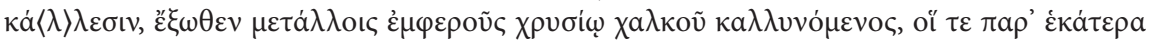

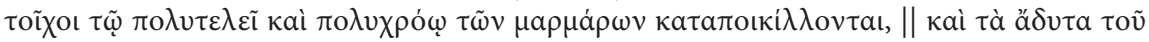

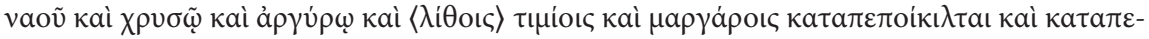

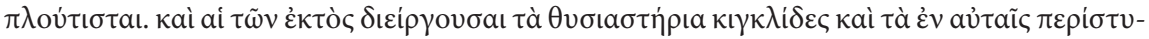

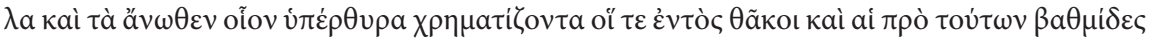

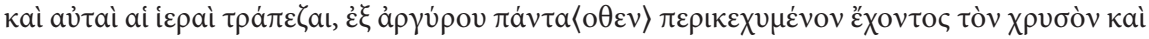

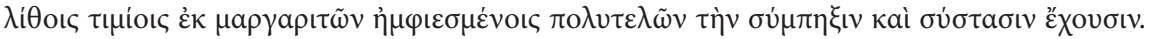

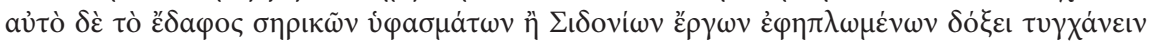

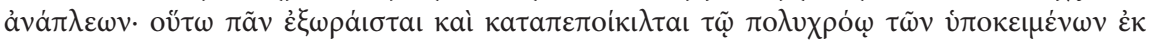

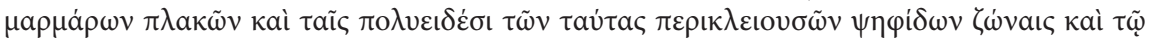

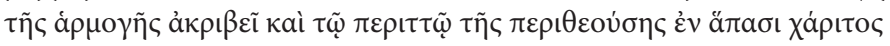

The emperor offered this church to Christ, the immortal Bridegroom, as a bride decked out and adorned with pearls and gold and gleaming silver and, moreover, with a variety of many-colored marbles, mosaic compositions and silken robes. The ceilings of that five-domed

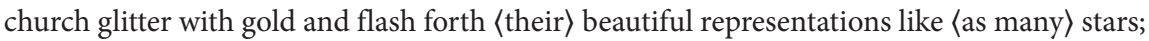
on the outside, the roof is embellished with brass work resembling gold; the shrine's 〈interior) walls on either side are varied with costly and many-colored marbles and its sanctuary is variously decked out with a wealth of gold, silver, precious stones and pearls. The chancel barrier that separates the outside area from the altar space; the colonnade set into this bar-

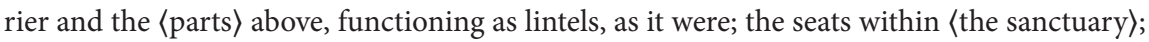
the steps leading to them; and the altars themselves are all given massivity and substance by

${ }^{42}$ Ibidem, p. $177-183$.

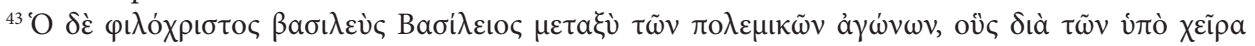

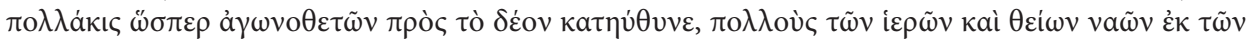

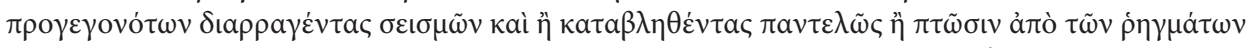

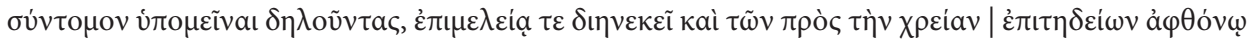

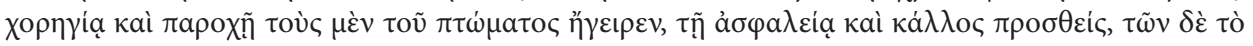

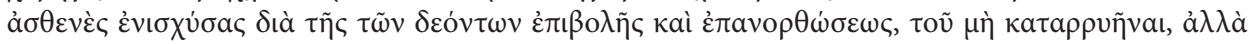

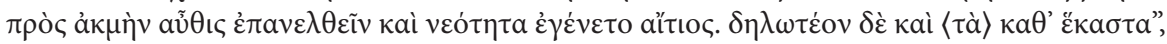

Chronographiae quae Theophanis Continuati nomine fertur Liber quo Vita Basilii Imperatoris amplectitur, 78, ed. I. ŠEvcenko, Berlin-Boston 2011 [= CFHB.SBe, 42] (cetera: Vita Basilii). 
silver that is gilded all over and 〈adorned with precious stones in settings made [?] from costly pearls. As for the pavement, it first will appear to be spread with 〈rugs $\rangle$ woven of silk or with Sidonian fabrics, so beautifully has all of it been inlaid and varied by marble panels of many hues set into the ground; by the variegated mosaic bands that enclose these panels; by the precision with which everything has been joined together; and by the superabundant elegance spreading throughout ${ }^{44}$.

The quoted ekphrasis although quite extensive, does not contain many details - like that of Photius. This is another evocation of a dazzling imperial foundation which is composed primarily by the discussing of wonderful and expensive materials exploited in the church embellishment, namely: gold, silver, tesserae, fabrics, and various many-hued stones. In this instance, like in previous ones, the

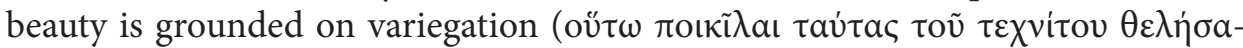

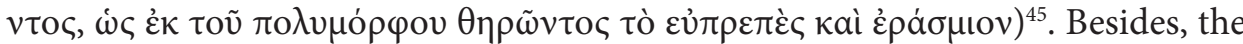
lavish decoration of the shrine is compared to the fine attire of a bride (öv $\dot{\omega} \varsigma$ $v \dot{\mu} \mu \varphi \eta v \dot{\omega} \rho a і ̈ \sigma \mu \varepsilon \dot{v} \eta v$ кaì $\pi \varepsilon \rho ı \varepsilon \kappa o \sigma \mu \eta \mu \varepsilon \dot{v} \eta v)$. This comparison also indicates that

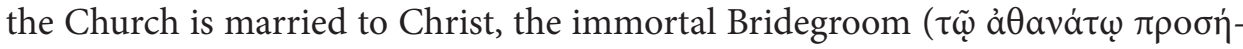

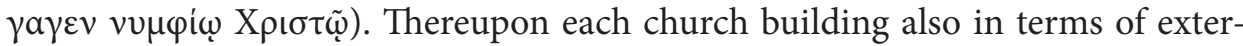
nal appearance must be appropriate for such a great Groom. On this account, the adorned "garment" of the New Church consists of marble cladding, mosaics, silk fabrics, pearls, gold, and silver. All these elements are costly and shiny, and they differ in colours as well.

Gold, probably in the form of tesserae, also covered the interiors of the five

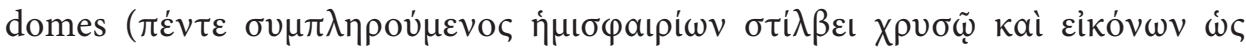

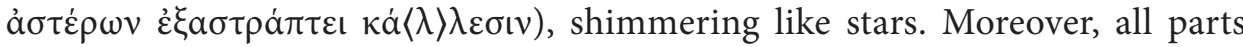
of the templon and the altars were made of silver and thereafter gilded ( $\dot{\varepsilon} \xi \dot{a} \rho \gamma \dot{v}-$

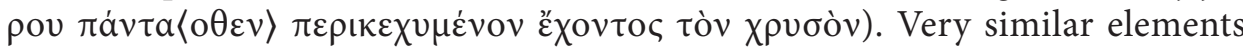
of a description are also found in the somewhat earlier poetic ekphrasis of the church of the Holy Apostles in Constantinople. It was written by Constantine of Rhodes (ca. 870 - after 931) who dedicated his work to Constantine VII

\footnotetext{
${ }^{44}$ Vita Basilii, 83.15-19, 84.1-18 (There are the Greek text and the English translation). Liutprand

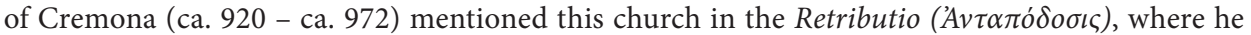
described his first diplomatic mission at the court of Constantinople, during the reign of Constantine VII Porphyrogenitus (913-959):

Fabricavit autem precioso et mirabili opere iuxta palatium orientem versus ecclesiam in honorem summi et caelestis militiae principis, archangeli Michahelis, qui Grece archistrátigos, hoc est miliciae princeps, apellatur. Ecclesiam autem ipsam Nean, hoc est novam, alii vocant, alii vero Ennean, quod nostra lingua novennalem sonat, appellant, eo quod ibidem ecclesiasticarum horarum machina novem pulsata ictibus sonet,

Liudprand de Crémone, Antapodosis, 3.34.555-560, [in:] Liudprand de Crémone, Euvres, ed. F. Bougard, Paris 2015 [= SHM, 41].

${ }^{45}$ Vita Basilii, 89.15-17.
} 
Porphyrogenitus (913-959) ${ }^{46}$. The poet mentioned there the names of the architects Anthemius of Tralles and Isidore of Miletus, known most of all from the design of the church of the Holy Wisdom, and stressed that due to their theoretical knowledge it was possible to erect such a magnificent building. The church of the Holy Apostles, however, was ravishing not only because of the engineering concepts but also because of the stunning decoration. The latter is compared to a bride

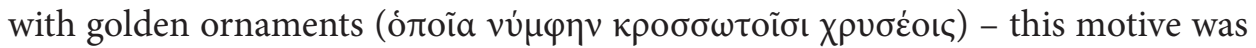
used, as we have seen, also in reference to the New Church - and to a wedding

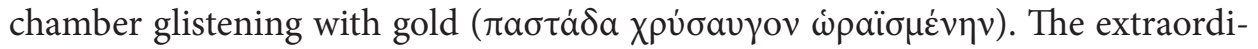
nary glow of the church interior is associated with gold, as well as with multicoloured marbles ( $\mu \alpha \rho \mu \alpha \dot{\rho} \rho \omega v \pi \mathrm{r} \lambda \nu \chi \rho \operatorname{có} \omega v)$, precious stones, and pearls giving fiery

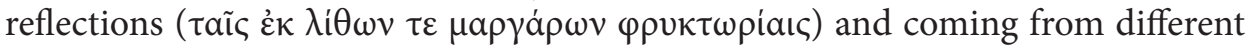

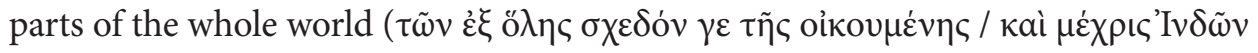

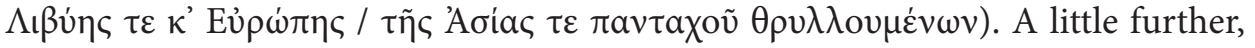
Constantine of Rhodes also pointed to golden tesserae ${ }^{47}$, against which - as can be

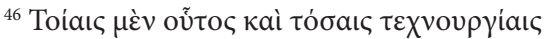

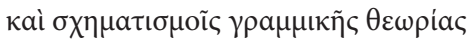

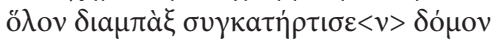

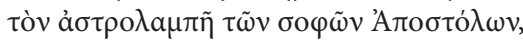

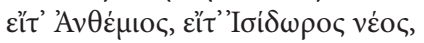

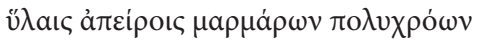

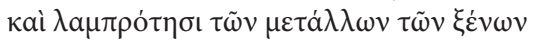

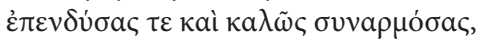

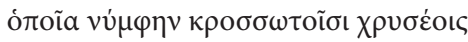

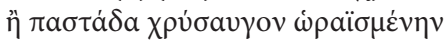

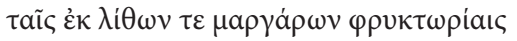

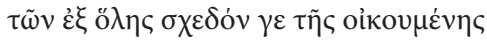

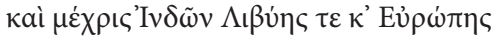

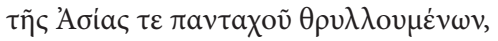

Constantine of Rhodes, On Constantinople and the Church of the Holy Apostles, 636-649, ed. L. James, I. Vassis, trans. V. Dimitropoulou, L. James, R. Jordan, Farnham 2012 (cetera: Constantine of Rhodes). Then follows the description of the used marbles. They, as we read,

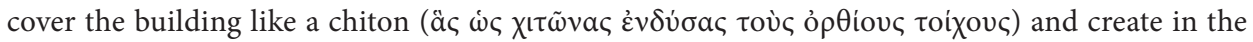
interior the impression of a meadow full of blooming flowers with colours reminiscent of precious stones (Constantine of RHodes, 650-674; 686-695). It is worth comparing this part of the ekphrasis to the some passages from the Silentiary's poem on the church of the Holy Wisdom, vide Paulus Silentiarius, 617-646.

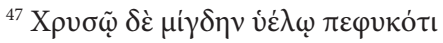

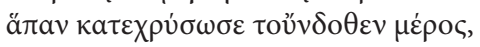

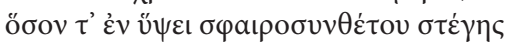

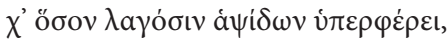

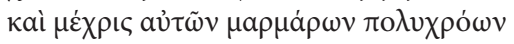

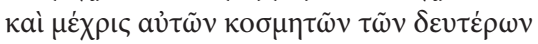


concluded from the description - scenes from the life of Christ were depicted ${ }^{48}$. It is noteworthy that the author had regard to technical detail, namely, that the gold-

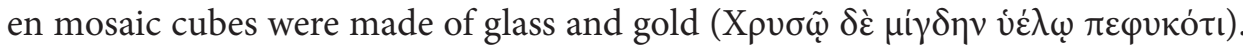

The golden glow was also associated with shiny fabrics, as evidenced, for example, by Silentiarius's ekphrasis of one of the silk purple fabrics ${ }^{49}$ prepared for the church of the Holy Wisdom:

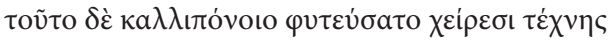

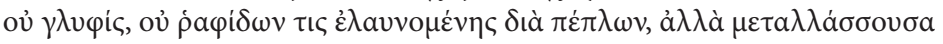

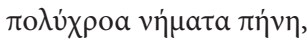

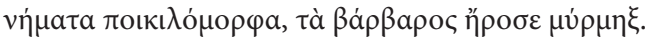

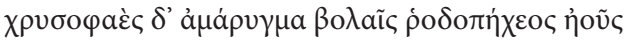

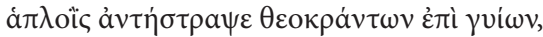

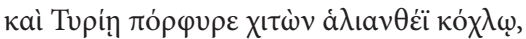

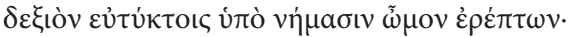

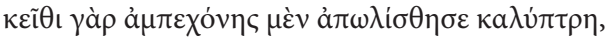

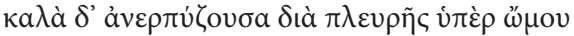

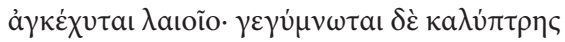

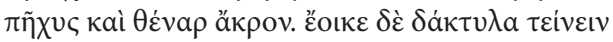

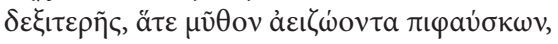

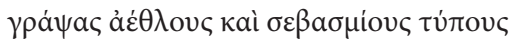

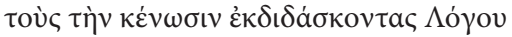

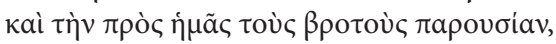

Constantine of Rhodes, 742-750.

${ }^{48}$ This is a quite long description, Constantine of Rhodes, 751-980. The church of the Holy Apostles in Constantinople was demolished in 1453, therefore a form of this church is reconstructed primarily on the basis of written sources, which include, first of all, the ekphraseis created by Procopius of Caesarea, Constantine of Rhodes, and Nicholas Mesarites. The earliest of them discussed only the architectural form, and the other two also depicted scenes. Perhaps these mosaic pictures were made during the reign of Basil I; L. JAmes, Constantine of Rhodes's Poem and Art History, [in:] CoNStantine of Rhodes, On Constantinople..., p. 181-217. On the place where the church was built: Constantinople. Archaeology of a Byzantine Megapolis. Final Report on the Istanbul Rescue Archaeology Project 1998-2004, ed. K. DARK, F. ÖzGüMüş, Oxford-Oakville 2013, p. 83-96. It is worth noting that there was a "Dumbarton Oaks Symposium" dedicated to this church (24-26 April 2015); M. Mullett, R. Ouserhout, The Holy Apostles. Dumbarton Oaks Symposium, 24-26 April 2015, DOP 70, 2016, p. 325-326; a collection of essays related to this conference has been recently published: The Holy Apostles - A Lost Monument, a Forgotten Project, and the Presentness of the Past, ed. M. Mullett, R.G. Ousterhout, Washington D.C. 2020 [= DOBSC].

${ }^{49}$ On various aspects of silk, as well as purple in Byzantium, i.a.: A. Muthesius, Byzantine Silk Weaving AD 400 to AD 1200, Vienna 1997; EAdem, Essential Processes, Looms, and Technical Aspects of the Production of Silk Textiles, [in:] The Economic History of Byzantium. From the Seventh through the Fifteenth Century, vol. I, ed. A.E. Laiou, Washington 2002, p. 147-168; A. Muthesius, Studies in Silk in Byzantium, London 2004; D. ЈАсову, Silk Production, [in:] The Oxford Handbook of Byzantine..., p. 421-428. Procopius of Caesarea described the history of silkworm smuggling, which was to be done by Byzantine monks: Procopii Caesarensis opera omnia. De bellis libri, 8.17.1-8, vol. II, ed. J. HAURY, rec. G. WirTh, Leipzig 1963 [= BSGR]. 


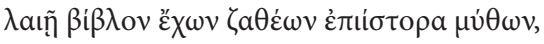

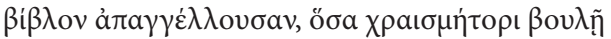

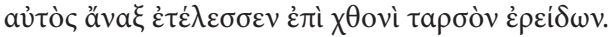

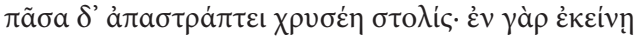

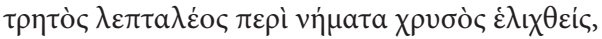

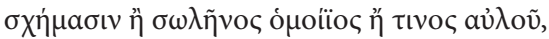

$\delta \varepsilon \dot{\sigma} \sigma \mu \varsigma$ í

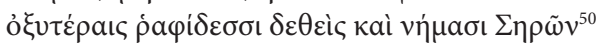

This has been fashioned not by artists' skilful hands plying the knife, nor by the needle driven through cloth, but by the web, the produce of the foreign worm, changing its colored threads of many shades. Upon the divine legs is a garment reflecting a golden glow under the rays of rosy-fingered Dawn, and a chiton, dyed purple by the Tyrian seashell, covers the right shoulder beneath its well-woven fabric; for at that point the upper garment has slipped down while, pulled up across the side, it envelops the left shoulder. The forearm and hand are thus laid bare. He seems to be stretching out the fingers of the right hand, as if preaching His immortal words, while in His left He holds the book of divine message - the book that tells what He, the Lord, accomplished with provident mind when His foot trod the earth. The whole robe shines with gold: for on it gold leaf has been wrapped round thread after the manner of a pipe or a reed, and so it projects above the lovely cloth, firmly bound with silken thread by sharp needles ${ }^{51}$.

The poet described the liturgical fabric that was laid on the altar. It was made of silk dyed with the Tyrian purple, and the figure of Christ Pantocrator was embroidered with gold thread. According to Silentiarius, this cloth glistened wonderfully in the morning sun, spreading the golden glare all-round. In the following lines, the author also referred to other scenes and persons, including Peter and Paul

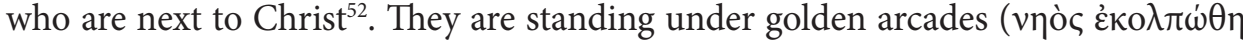

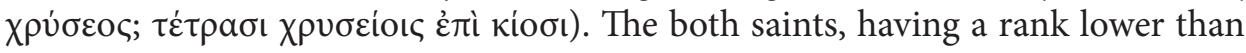

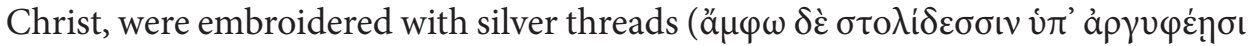

\footnotetext{
${ }^{50}$ Paulus Silentiarius, 765-785.

${ }^{51}$ C. Mango, The Art of the Byzantine..., p. 88-89.

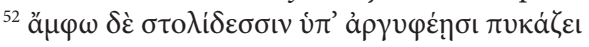

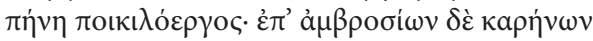

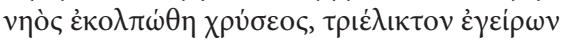

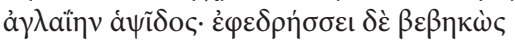

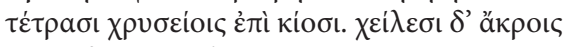

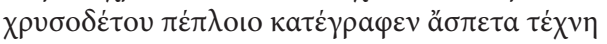

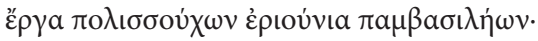

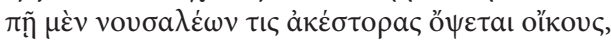

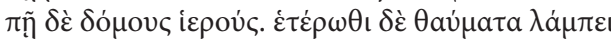

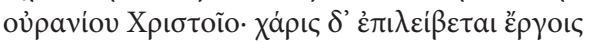

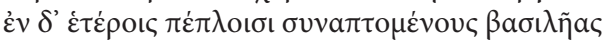

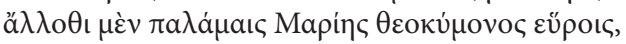

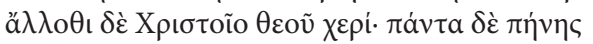

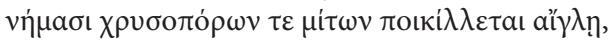
Paulus Silentiarius, 792-805.
} 


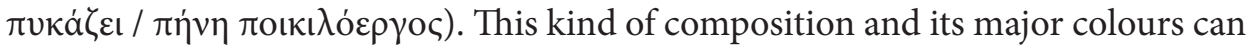
bring to mind the fantastic architecture, which is depicted in the mosaics in the dome of the Rotunda in Thessalonica ${ }^{53}$. This architecture was depicted primarily of gold mosaic cubes, and it also frames the figures of standing saints or courtiers. In the case of the described fabric, buildings funded by emperors as well as the scenes of Christ's miracles were embroidered with gold thread ${ }^{54}$. As a result, the cloth is beautiful because of the content shown and the craftsmanship, and it is lighted by the golden glow of the threads.

It should be noted that examples of this kind of fabric's ekphraseis are quite numerous, especially in the late antique Latin literature ${ }^{55}$. At that time, imperial and consular robes were widely described. This theme was popular because it gave the opportunity - as in the case of architecture - to present splendid objects made of expensive, multi-coloured, and shiny materials ${ }^{56}$. In the context of this so-called "jeweled aesthetics", it is worth citing some passages from the semi-legendary

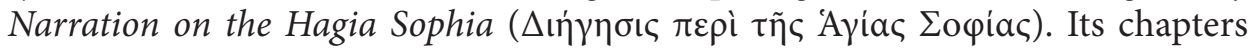

${ }^{53}$ On the Rotunda cf.: C. Bakirtzis, P. Mastora, Are the Mosaics in the Rotunda into Thessaloniki Linked to its Conversion to a Christian Church?, HB 9, 2011, p. 33-46; C. BAKIRTZIs, Rotunda, [in:] Mosaics of Thessaloniki $4^{\text {th }}-14^{\text {th }}$, ed. IDEM, trans. A. Doumas, Athens 2012, p. 51-117; H. TorP, La rotonde palatine à Thessalonique. Architecture et mosaïques, vol. I, Athènes 2018, p. 17-18, 445-466; IDEM, Considerations on the Chronology of the Rotunda Mosaics, [in:] The Mosaics of Thessaloniki Revisited. Papers from the 2014 Symposium at the Courtauld Institute of Art, ed. A. EASTmond, M. Hatzaki, Athens 2017, p. 35-47; L. James, Mosaics in the Medieval World. From Late Antiquity to the Fifteenth Century, Cambridge 2017, p. 174-179.

${ }^{54}$ Cyril Mango indicates that the linen fabric with the scene of the Daniel in the Lions' Den which is in the collection of the Kunstgewerbemuseum in Berlin (Fragment eines Behanges mit Daniel in der Löwengrube, http://www.smb-digital.de/eMuseumPlus?service=ExternalInterface\&module $=$ collecti on\&objectId=1965177\&viewType=detailView [16 V 2020]) corresponds to the description of Silentiarius. Churches and the miracles of Christ are depicted on the linen fabric's hems; C. Mango, The Art of the Byzantine..., p. 89, n. 165; J. STRZYGOwsкi, Orient oder Rom. Beitrag zur Geschichte der spätantiken und frühchristlichen Kunst, Leipzig 1901, p. 91-98 (il. IV, 41-42).

${ }_{55}^{5}$ M. Roberts, The Jeweled..., p. 111-116.

${ }^{56}$ E.g.: Claudian, Panegyric on Probinus and Olybrius, 190-207, [in:] Claudian, Panegyric on Probinus and Olybrius. Against Rufinus 1 and 2. War against Gildo. Against Eutropius 1 and 2. Fescennine Verses on the Marriage of Honorius. Epithalamium of Honorius and Maria. Panegyrics on the Third and Fourth Consulships of Honorius. Panegyric on the Consulship of Manlius. On Stilicho's Consulship 1, vol. I, ed. M. Platnauer, Cambridge Mass. 1922 [= LCL, 135]; Claudian, Panegyric on the Fourth Consulships of Honorius, 585-609, [in:] Claudian, Panegyric on Probinus and Olybrius. Against Rufinus...; Claudian, On Stilicho's Consulship 2-3, 2.339-389, [in:] Claudian, On Stilicho's Consulship 2-3. Panegyric on the Sixth Consulship of Honorius. The Gothic War. Shorter Poems. Rape of Proserpina, vol. II, ed. M. Platnauer, Cambridge Mass. 1922 [= LCL, 136]; Claudian, Rape of Proserpina, 1.245-287, [in:] Claudian, On Stilicho's Consulship 2-3. Panegyric...; Claudian, Panegyric on the Sixth Consulship of Honorius, 177-192, [in:] Claudian, On Stilicho's Consulship 2-3. Panegyric...; Sidonius, Poems and Letters, 15.126-195, vol. I, ed. W.B. Anderson, Cambridge Mass. 1936 [= LCL, 296]; Flavius Cresconius Corippus, In laudem Iustini Augusti minoris. Libri IV , 1.275-290, ed. Av. Cameron, London 1976. 
$15-19,21-24$, and 26 relate mainly to costly materials used in the church. In most cases, there are not many detailed descriptive parts among them: only two of them are quite extensive ekphraseis. The first one refers to the altar commissioned by Justinian I (527-565):

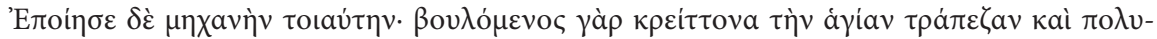

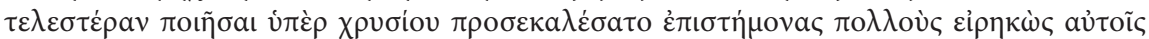

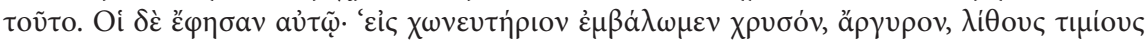

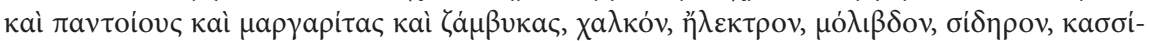

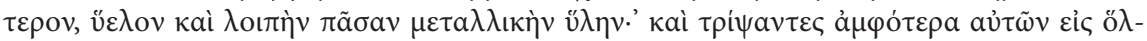

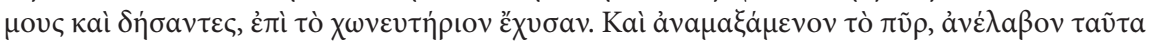

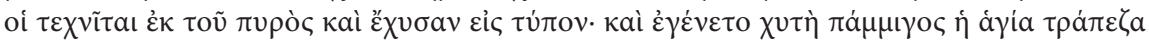

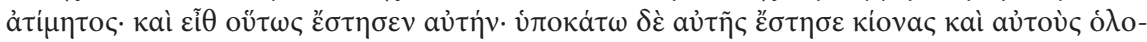

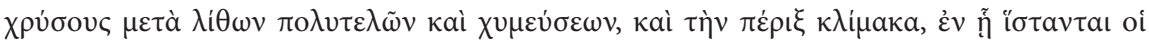

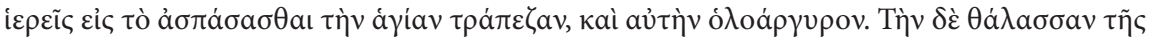

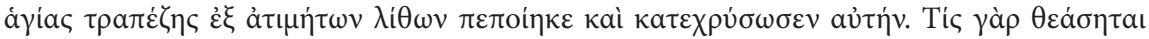

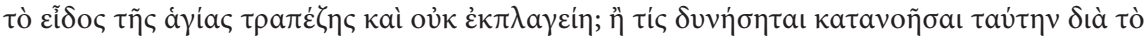

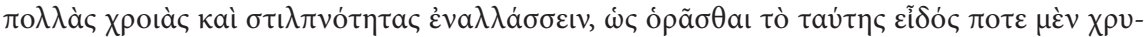

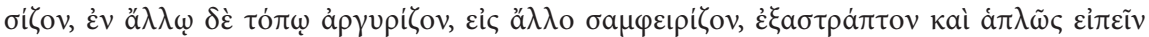

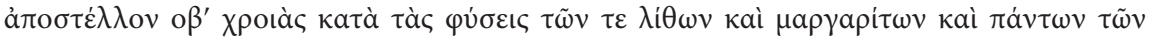
$\mu \varepsilon \tau \dot{\alpha} \lambda \lambda \omega v ; ;^{57}$

He also make the following contrivance. Wishing to make the holy altar table better and more precious than gold, he consulted many wise men and told them so. They said to him. "Let us throw gold, silver, various precious stones, pearls and mother of pearl, bronze, electrum, lead, iron, tin, glass and every other metallic material into melting furnace." Having crushed and bound all of these in mortars, they poured them into the melting furnace. And when the fire had kneaded these together, the craftsman took them out of the fire and poured them into a casting mold. And so the altar table was cast, made up of all materials and priceless. And then he set it up in this manner, and placed columns of pure gold under it with precious stones and enamels; and he made the surrounding stairs, on which the priests stand when they kiss the holy altar table, also of pure silver. He made the liturgical basin (thalassa) of the altar table of priceless stones and gilded it. So who can behold the beauty of the holy altar table and not be amazed? Or who can comprehend it as its many colors and brilliances change, so that it appears sometimes as gold, in other places as silver, elsewhere gleaming with sapphire - radiating and, in a word, sending out seventy-two colors according to the nature of the stones, pearls and all the metals? ${ }^{28}$.

In this description, where gold is a synonym of the most valuable substance, Justinian, however, managed to find a way to obtain a material even more won-

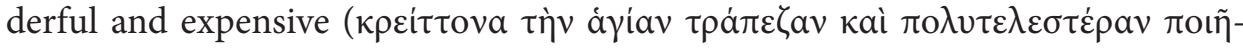

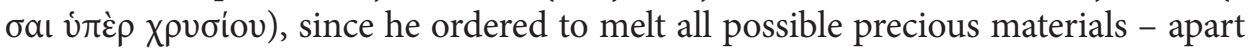

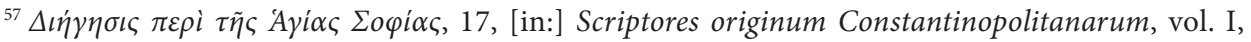
ed. T. Preger, Leipzig 1901 (cetera: Narration).

${ }^{58}$ Accounts of Medieval Constantinople. The Patria, 17, trans. A. Berger, Cambridge Mass.-London 2013 (cetera: Patria), p. 257, 259 [= DOML, 24].
} 
from gold also silver, electrum, bronze, pearls, and precious stones - along with more common metals - i.e. lead, iron, tin, and with glass - in one crucible. Consequently, a priceless mixture ( $\pi \dot{\alpha} \mu \mu \imath \gamma \circ \varsigma \dot{\alpha} \tau \dot{\mu} \mu \eta \tau \varsigma \varsigma)$ was created. As we read, it was characterized by a multitude of colours and it shimmered in different ways, like the materials of which it was made. It can be assumed that the author, explaining how the altar was built, above all tried to emphasize the emperor's involvement and generosity, as he cumulated the most expensive materials for the most vital part of the church's furnishings. Therefore, this description should not be taken literally ${ }^{59}$. In turn, the seventy-two colours probably allude to the number of disciples sent by Christ to preach the Gospel ${ }^{60}$. Importantly, an anonymous author of the Narration clearly stressed a brilliance and colourfulness of the costly materials. In the second ekphrasis - regarding the floor and symbolic interpretation of the

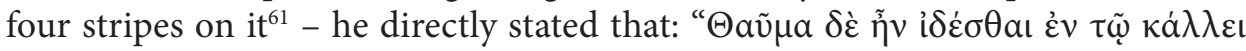

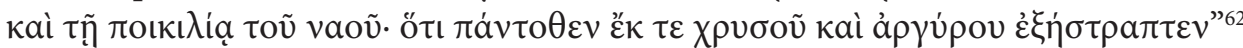
(It was wonderful to see the beauty and variety of the church, for it shone all around with gold and silver) ${ }^{63}$. Thus, the most prized aesthetic value is still the variega-

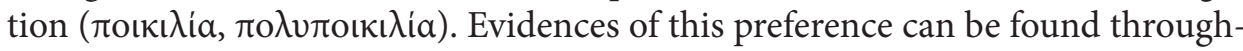
out the text, since it glitters with precious and shiny materials such as, among

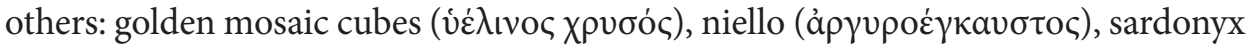

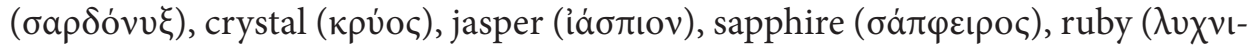

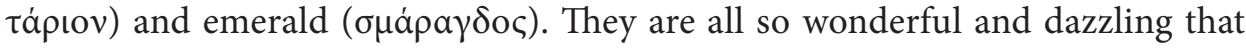

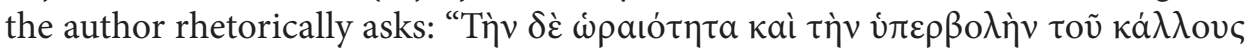

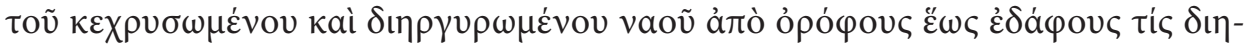

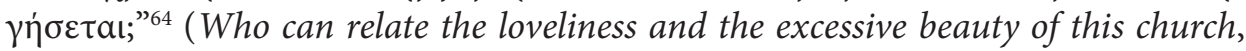
gilded and sheathed with silver from ceiling to floor?) ${ }^{65}$.

From the texts discussed so far, it follows that gold was valued primarily for its extraordinary glow - sometimes even too blinding - with which light was

\footnotetext{
${ }^{59}$ Cf. L. Brubaker, Talking about the Great Church. Ekphrasis and the "Narration on Hagia Sophia", Bsl 69.3, 2011, p. 82.

${ }^{60}$ Cf. Lc 10, 1.

${ }^{61}$ The author interpreted these stripes as the Paradise rivers. At the end of chapter 28 , where he discussed the reconstruction of the church after the collapse of the dome on the $7^{\text {th }}$ of May 558, the author pointed out that the pavement was almost entirely made of the Proconesian marble, only the strips were of a green stone. He did not provide information about the place of its origin, but it

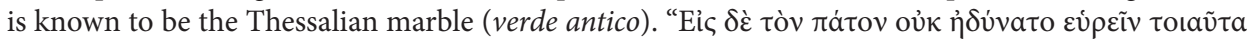

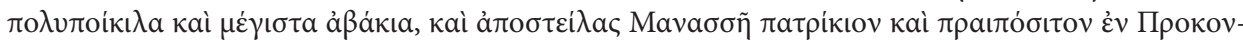

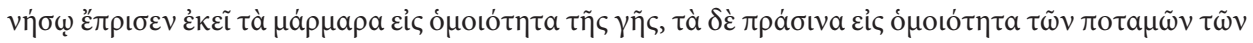

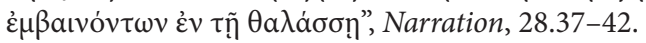

${ }^{62}$ Narration, 26.23-25.

${ }^{63}$ Patria, 26, p. 265.

${ }^{64}$ Narration, 26.3-5.

${ }^{65}$ Patria, 26, p. 267.
} 
inevitably related. The authors, as could be seen, regularly point out that rays falling on golden surfaces are reflected from them, scattering golden reflections allround. Thus, the aforementioned "jeweled aesthetics" do not exist without light, because it "triggers" these, described with pleasure and highly praised, characteristic visual effects. Hence, gold needs a light source to fully show its beauty. In turn, the light can take dazzling colour of gold. It is not surprising, then, that Sergey Averintsev termed gold the "absolute metaphor of light" 66 .

In the accounts of Byzantine writers, gold is also a colour, although this issue was considered less often because in terms of colours marbles and precious stones were much more praised. They were, as already mentioned, compared to meadows in full bloom. All the more, it is worth quoting a passage from the already cited homily of Leo VI, where he explains the reason for using golden mosaic cubes in the church:

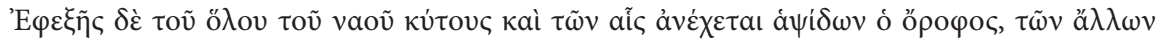

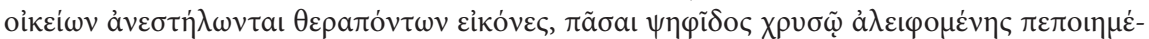

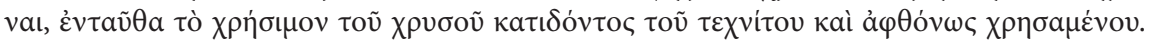

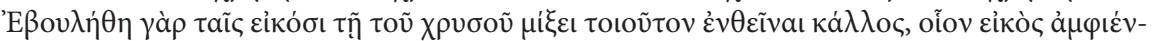

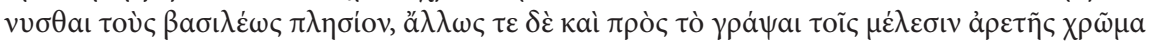

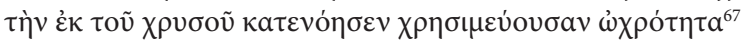

The rest of the church's hollow and the arches on which the roof is supported have images of [God's] own servants, all of them made of mosaic smeared with gold. The craftsman has made abundant use of gold whose utility he perceived: for, by its admixture, he intended to endow the pictures with such beauty as appears in the apparel of the emperor's entourage. Furthermore, he realized that the pallor of gold was an appropriate color to express the virtue of [Christ's] member ${ }^{68}$.

The emperor points out there that the pale hue of gold ( $\omega x \rho$ ó $\tau \eta \tau \alpha)$ reminds

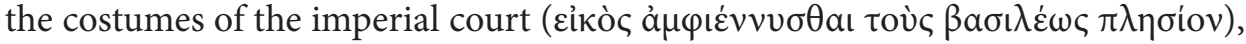
and that it is suitable for the images of saints because it emphasises their saint-

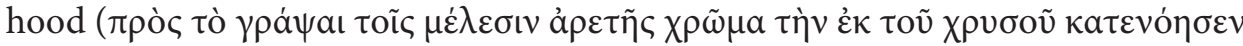
$\left.\chi \rho \eta \sigma \mu \varepsilon \dot{o v \sigma \alpha} v \dot{\omega} \chi \rho \dot{x}^{\tau} \eta \tau \alpha\right)$. In this context, it is also worth paying attention to the short poem of Eugenius of Palermo (ca. 1130-1202) dedicated to the image of Saint John Chrysostom:

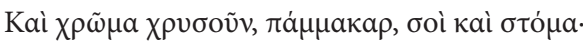

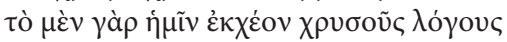

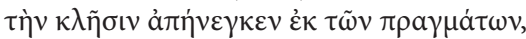

\footnotetext{
${ }^{66}$ S. AWIERINCEW, Złoto..., p. 184.

${ }^{67}$ LEO VI, 31.70-78.

${ }^{68}$ C. Mango, The Art of the Byzantine..., p. 203.
} 


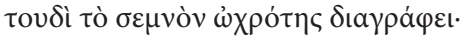

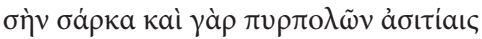

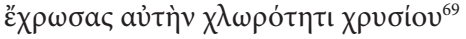

All blessed one, both your color and your voice are golden.

For the one [your voice], pouring out to us golden words,

took its name from your deeds,

while pallor delineates the holiness of your color.

For consuming your flesh by the fire of fasting,

you have tinged it with the pallor of gold ${ }^{70}$.

In this case, the poet specified that the golden colour - due to its pallor ( $\omega x p o$ $\tau \eta \varsigma, \chi \lambda \omega \rho$ ó $\tau \varsigma)$ - was very suitable for the representation of the ascetic saint whose body, experienced by fasting, lost its more vivid colours.

The beauty of gold was also associated with splendour. This question was also raised, e.g., by Choricius of Gaza (491-518) in the ekphrasis of the church of St. Stephen at Gaza:

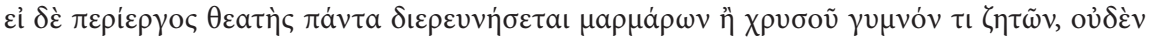

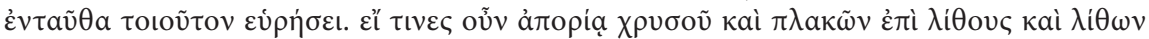

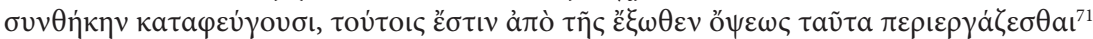

The curious observer may look high and low in search of a spot bare of either marble or gold: he will not find one here. Those who are embarrassed by [so much] gold and marble, and seek relief in stones and masonry, will be able to study the latter on the outside ${ }^{72}$.

The effulgent embellishment of the church consists of gold and marble revetment. They contrast with the outside stone walls which can provide a respite from the richness of the interior. Recognizing that this type of decoration could be too overwhelming to spectators, the author also hurried to explain that the building has a very good style that would only be appreciated by true art experts. Of course, there is a trap here: those who perceive a building negatively have no knowledge of $\operatorname{art}^{73}$. Choricius, though sure of the incomparable beauty of the church, made

${ }^{69}$ Eugenius Panormitanus, In imaginem Chrysostomi, 11, [in:] Versus Iambici, ed. M. Gigante, Palermo 1964 [= TMon, 10].

${ }^{70}$ H. Maguire, Nectar..., p. 130.

${ }^{71}$ CHORICIUS, 2.2.49.

${ }^{72}$ C. Mango, The Art of the Byzantine..., p. 71-72.

${ }^{73}[\ldots]$ б ${ }^{2}$.

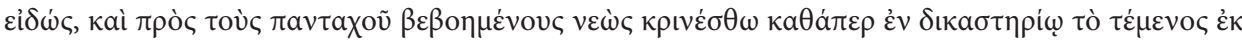

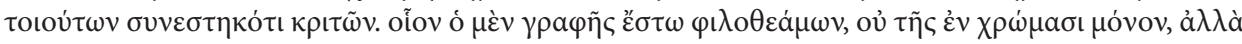

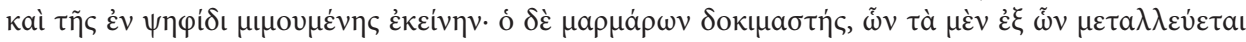

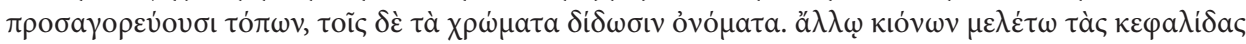


it clear that the right proportions must be respected in the use of gold, because both an excess and a shortness is wrong. Just from this one example, it can be seen that the attitude to gold was to some extent marked by suspiciousness. The authors often felt obliged to clarify that the decorations of gold did not exceed the appropriate measure (á $\mu \varepsilon \tau \rho i \alpha)$ : gold is beautiful, but it is necessary to use it purposefully and decorously.

Against a backdrop of the moderation in a use of gold, the description of the church of Saint George in the Mangana quarter ${ }^{74}$ written by Michael Psellos (ca. 1017-1078?) is an interesting example. He characterised the church rebuilt by Constantine IX Monomachos (1042-1055) as a combination of beauty and luxury:

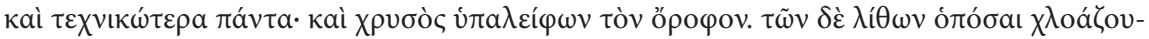

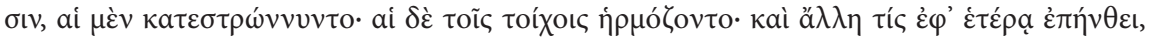

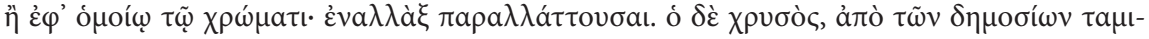

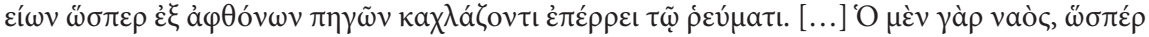

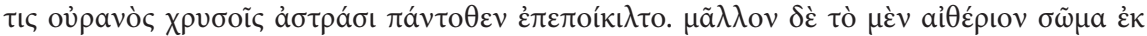

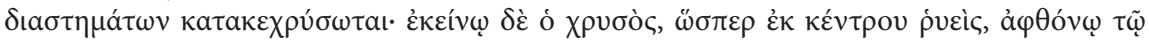

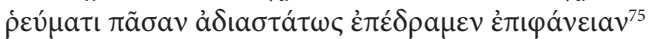

Everything was made more artful, the ceiling was covered with gold, slabs of a verdant color were laid in the pavement and affixed to the walls, and each kind of marble bloomed next to another which was either of the same or of contrasting hue. And gold flowed in a torrential stream from the public treasury as from an inexhaustible source. [...] Indeed, the church was

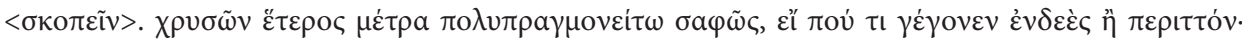

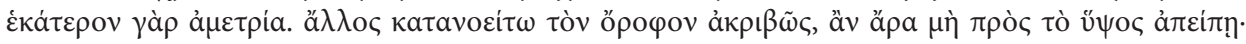

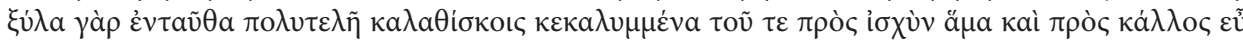

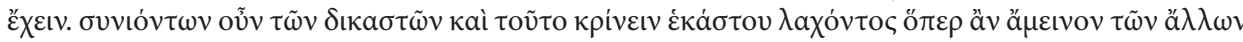

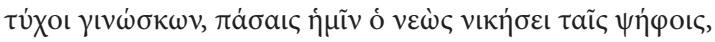

CHORICIUs, 2.2.52-54.

${ }^{74}$ In the History of Niketas Choniates, we read that Isaac II Angelos (1185-1195) destroyed this church with the adjacent palace, and the building materials obtained during this demolition were then used for other edifices:

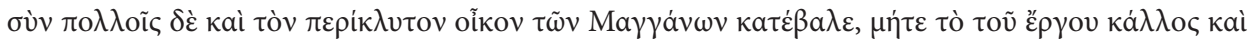

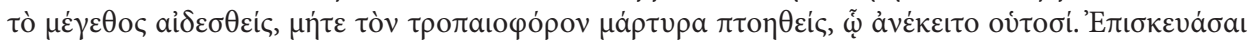

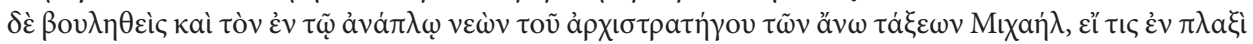

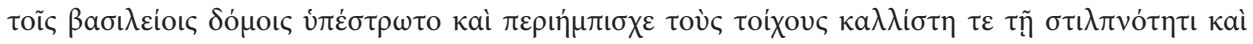

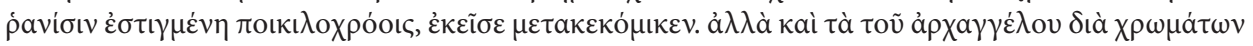

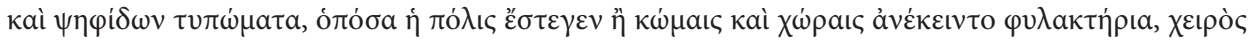

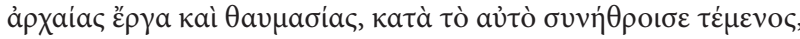

Nicetae Choniatae historia, pars prior, Isaac2, pt3, ed. J. van Dieten, Berlin 1975 [= CFHB.SBe, 11.1], p. $442.18-27$.

${ }^{75}$ Michaelis Pselli Chronographia, 6.185.13-18; 6.186.10-14, ed. D.R. ReInsch, Berlin-Boston 2014 [= Mil.S, 51] (cetera: Psellos). 
like the sky adorned on all sides with golden stars; to be more exact, the heavens are gilded only at intervals, while here the gold, flowing as it were, from the center in a copious stream, has covered the entire surface without interruption ${ }^{76}$.

Although Psellos admired this church, he also recognized it as a crowning example of the exaggeration of the emperor who wanted to surpass all other churches:

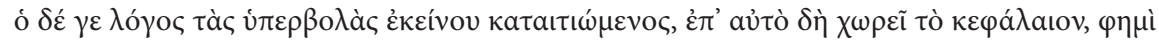

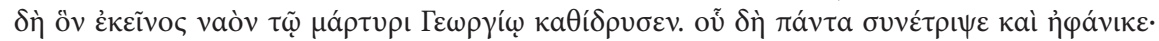

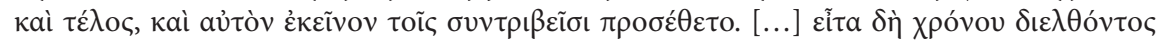

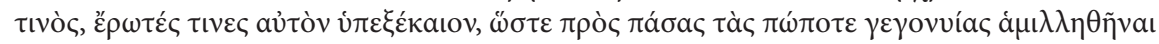

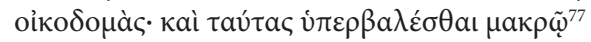

My indictment of his [Constantine IX's] excesses now comes to its principal point, namely the church he founded in honor of the martyr George, which he then entirely destroyed and wiped out, and [after rebuilding it] reduced it once again to ruin. [...] Later on, however, he became consumed by the passion of rivalling all the buildings of the past and even surpassing them by far ${ }^{78}$.

Therefore, Psellos heavily criticised exaggerated aspirations of the emperor, and the ruler's intention was decisive for considering the church too luxurious. However the funding of various edifices was a quite significant task of emperors, sometimes they were reprehended for the activity of this sort. It could also be a way of showing general disapproval of the policy pursued by a given emperor, just to mention the particularly symptomatic case of Procopius of Caesarea ${ }^{79}$.

In the case of art, splendour of gold could be very desirable, as evidenced by epigrams devoted to icons made of precious materials or, at least, clad with them ${ }^{80}$. And to give an example, Nicholas Kallikles (ca. 1080 - ca. 1150) prepared a poem for an icon of Christ, which John II Komnenos (1118-1143) commissioned for the Pantokrator Monastery in Constantinople:

${ }^{76}$ C. Mango, The Art of the Byzantine..., p. 219.

${ }^{77}$ Psellos, 6.185.1-5; 6.185.8-11.

${ }^{78}$ C. Mango, The Art of the Byzantine..., p. 218.

${ }^{79}$ Cf. Procopius, 1.1.11-12, 1.1.17-19; Procopii Caesarensis opera omnia. Historia quae dicitvr arcana, 8.7-9; 11.3-4; 19.6; 26.23-24, vol. III, ed. J. HAURY, rec. G. WIRTH, Leipzig 1963 [= BSGR].

${ }^{80}$ On precious-metal icon revetments i.a.: A. GrabaR, Les revêtements en or et en argent des icônes byzantines du Moyen Âge, Venise 1975; N. Patterson ŠEvčEnko, Vita Icons and "Decorated" Icons of the Komnenian Period, [in:] Four Icons in the Menil Collection, ed. B. Davezac, Houston 1992, p. 57-69; T. Papamastorakis, The Display of Accumulated Wealth in Luxury Icons. Gift-Giving from

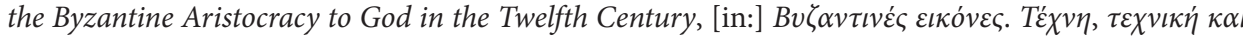

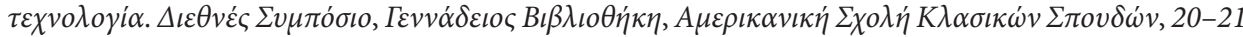

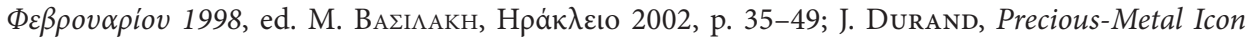
Revetments, [in:] Byzantium. Faith and Power (1261-1557), ed. H.C. Evans, New York-New Haven 2004, p. 243-251. 


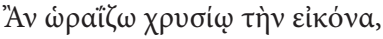

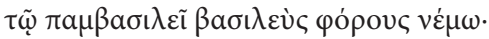

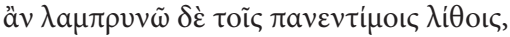

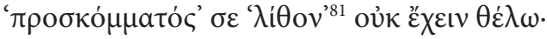

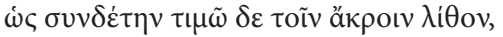

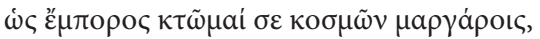

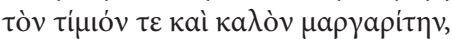

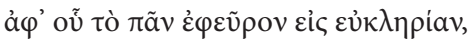

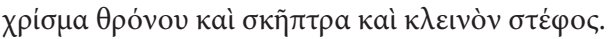

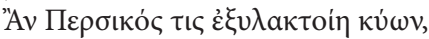

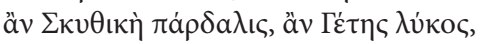

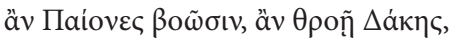

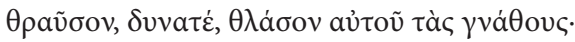

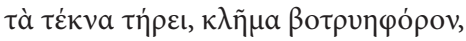

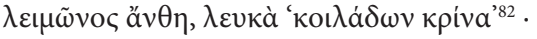

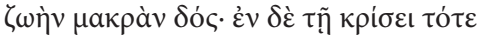

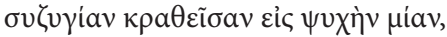

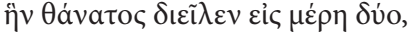

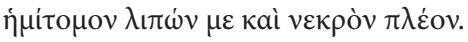

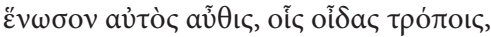

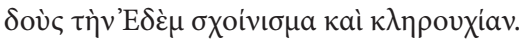

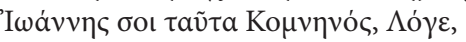

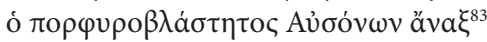

When I beautify your icon with gold, I, the king, pay tribute to the king of all. When I [make it] glitter with precious stones, I do not want you [to be] an "obstructing stone", for I honour you as [the] cornerstone that unites all extremities. And thus, like a merchant I attain you and adorn you with pearls, you, the worthy and beautiful pearl, from whom I have won all my good fortune: an anointed throne, and sceptre, and glorious crown. Should some Persian dog, Scythian leopard, or Hungarian wolf howl, should Panonians clamour and Dacians mount [their chargers], strike them, O powerful one, smash their jaws.

Protect my offspring, the vine's fruit, the flowers of the meadow, the white "lilies of the valley" give [them] long life. And in that future judgement let me be united with my consort in a single soul that death divided in twain, leaving me half and already dead.

Unite that man immediately, as you know how,

${ }^{81}$ Cf. Rom 9, 33.

${ }^{82}$ Cf. Ct 2, 1.

${ }^{83}$ Nicola Callicle, Carmi, 2.12-34, ed. R. Romano, Napoli 1980 [= BNN, 8]. 
bestowing the garden of Eden as [his] lot.

So these things I, John Komnenos, [address] to you, O Word,

I, the king of the Ausonites, sprung from the purple ${ }^{84}$.

This emperor also funded another icon of Christ, which is associated with an

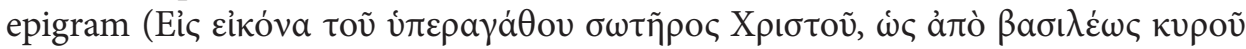
'I $\omega$ ávvov) written by Theodore Prodromos (ca. 1100 - ca. 1165):

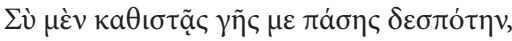

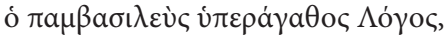

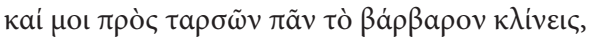

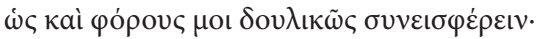

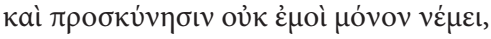

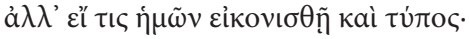

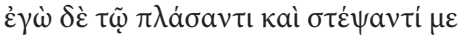

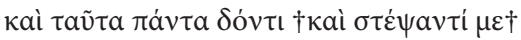

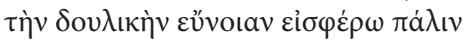

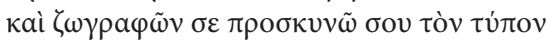

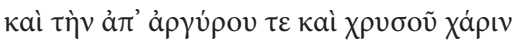

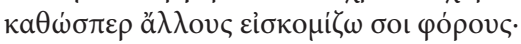

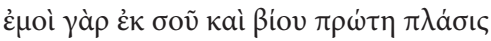

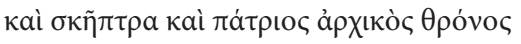

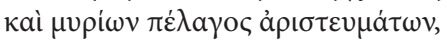

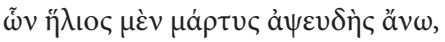

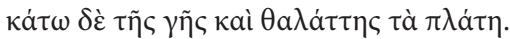

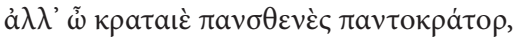

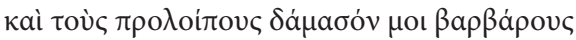

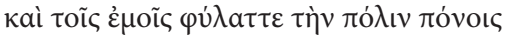

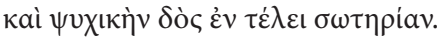

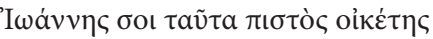

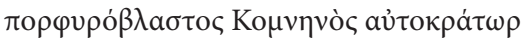

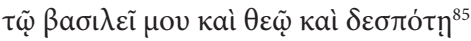

You who made me lord of all the world,

You the King of All and abundantly good Logos

who makes all barbarians bow at my feet,

and pay servile tribute to me.

It is not to my person alone that they bow down

but wherever else the image of our features is depicted.

I, to Him that made and crowned me,

once again pay the homage of a slave,

and painting you I venerate your form;

adorning you with gold and silver

is my way of paying you tribute.

To you I owe both life's existence

${ }^{84}$ T. Papamastorakis, The Display..., p. 37-38.

${ }^{85}$ Theodoros Prodromos, Historische Gedichte, 21, ed. W. Hörandner, Wien 1974 [= WBS, 11]. 
and my royal sceptre,

and the throne inherited from my father,

and a sea of myriad trophies

of which above the sun is unimpeachable witness

and below, the breadth of sea and earth.

But, O sovereign and all-powerful Pantokrator,

rein in for me the remaining barbarians,

and preserve my city through my own pains,

and at the end give my soul salvation.

The emperor Komnenos sprung from the purple,

to my king and God and Lord ${ }^{86}$.

In the both poems, the emperor decided to commission an icon decorated with expensive materials - in the first case they are gold, pearls, and precious stones, in the second one - silver and gold. The descriptions are quite general, but it can be assumed that these materials formed revetments: it is especially likely in the last epigram, where both the painting layer and adornment are dis-

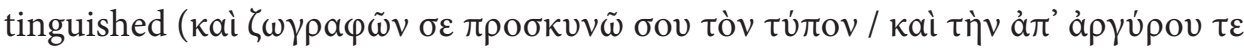

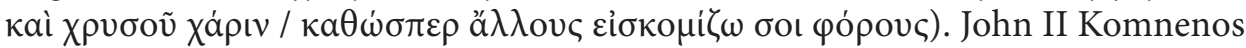
chooses these gifts to thank for all the favours he has received so far and to ask God for further support in both state and personal matters. The emperor presents himself as the greatest earthly ruler who addresses the supreme king, therefore the gift must be worthy of both of them. In the context of material goods, precious metals and stones are the most valuable. Hence, Komnenos intended them to deck the images of Christ. There are more Byzantine poems composed around the problem of icons with precious-metal revetments, which proves the popularity of the motif and this type of votive gifts as well ${ }^{87}$.

Costly and shiny materials creating a dazzling decoration were suitable not only for churches but also for the imperial court. In ekphraseis of imperial residences, the richness of the materials used - as well as the way they are characterised - virtually does not differ from that employed for descriptions of religious architecture. In this context, it is worth quoting the ekphrasis of the palace of Digenis Akritis. His residence is an example of unreal architecture, created for the purpose of the poem, therefore it is more magnificent than any real palace:

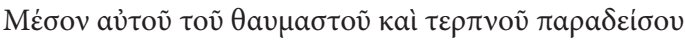

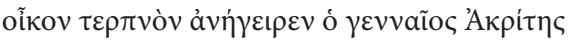

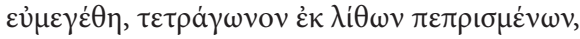

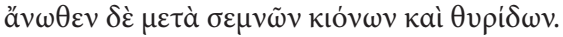
Toù ỏ ó

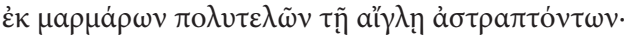

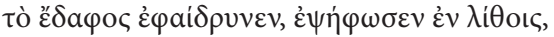

${ }^{86}$ T. Papamastorakis, The Display..., p. 38.

${ }^{87}$ Ibidem, p. 39-47. 


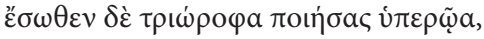

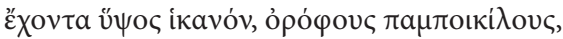

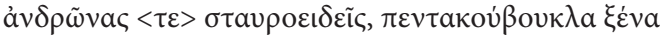

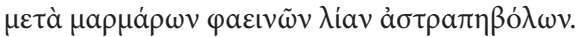

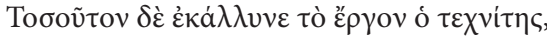



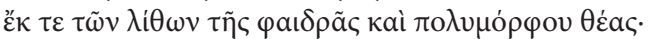

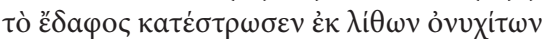

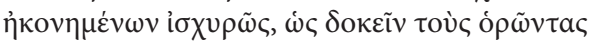

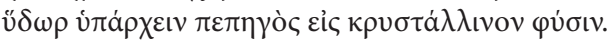

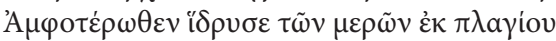

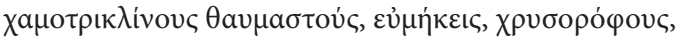

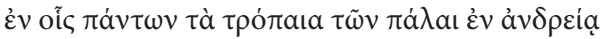

$\lambda \alpha \mu \psi \alpha \dot{v} \tau \omega \nu v a ̉ v ı \sigma \tau o ́ \rho \eta \sigma \varepsilon \chi \rho v \sigma o ́ \mu o v \sigma \alpha$, $\dot{\omega} \rho a i a^{88}$

In the midst of this wonderfully pleasant garden the noble Akrites erected a big square house of cut stone having stately columns and windows up above. He adorned all the ceilings with mosaic, he decorated the pavement with precious gleaming marbles and tesserae of stone. Inside he made upper chambers on three floors having sufficient height and decorated ceilings; [he also made] cruciform halls, strange pentacubicula, containing shining marbles reflecting shafts of light. So beautiful was the artist's work that the gay, many-figured aspect of the stones made one think of woven tapestry. He paved the floor with onyx so smoothly polished that those who saw it mistook it for water congealed to ice. On either side he set up long, wondrous reclining-rooms having golden ceilings upon which he represented in mosaic the victories of all those men of yore who shone in valor ${ }^{89}$.

In the description of the residence of Akritis, sparkling marbles ( $\dot{\varepsilon} \kappa \mu \alpha \rho \mu \alpha \dot{\alpha} \rho \omega v$

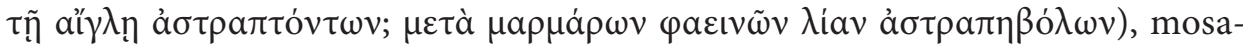
ics ( $\dot{\varepsilon} \varphi \alpha i \delta \rho v v \varepsilon v, \dot{\varepsilon} \psi \eta \dot{\varphi} \varphi \omega \sigma \varepsilon v \dot{\varepsilon} v \lambda i \theta o ı s, \chi \rho v \sigma o ́ \mu o v \sigma \alpha)$, and gilded ceilings ( $\chi \rho v-$

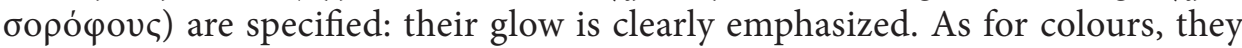
are actually not particularised. This imagined palace is described in accordance with the established convention, and - due to the epic character of the poem - all the features are exaggerated and idealised. As the Akritis' residence is an example of fantastic architecture, so its opposite is the palace Muchrutas, which brief ekphrasis was composed by Nicholas Mesarites (ca. 1163 - after 1216). It is a very interesting text because in this case, the author had to face the necessity of crossing the formulaic patterns since the building was erected in a style referring to Muslim architecture:

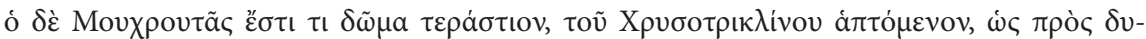

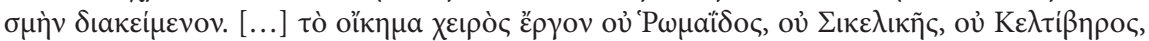

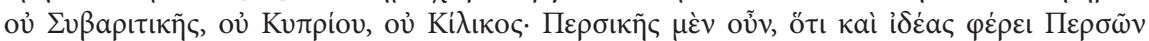

\footnotetext{
${ }^{88}$ Digenis Akritis, The Grottaferrata and Escorial versions, 7.13-41, ed. E. Jefrereys, Cambridge 1998 [= CMC, 7].

${ }^{89}$ C. Mango, The Art of the Byzantine..., p. 215-216.
} 


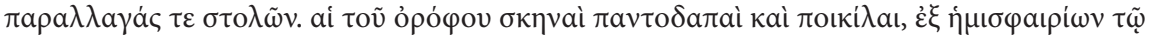

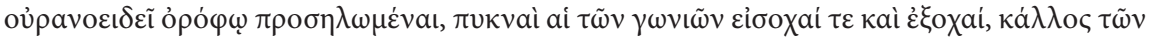

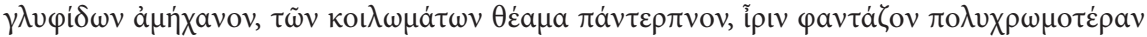

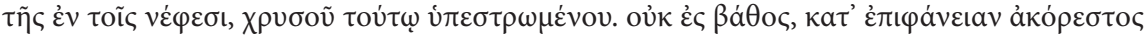

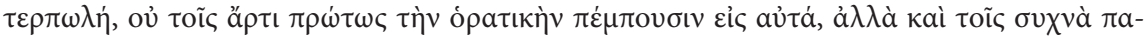

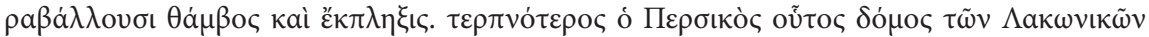

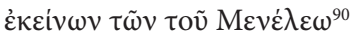

The Mouchroutas is an enormous building adjacent to the Chrysotriklinos, lying as it does on the west side of the latter. [...] This building is the work not of a Roman, nor a Sicilian, nor a Celt-Iberian, nor a Sybaritic, nor a Cypriot, nor a Cilician hand, but of a Persian hand, by virtue of which it contains images of Persians in their different costumes. The canopy of the roof, consisting of hemispheres joined to the heaven-like ceiling, offers a variegated spectacle; closely packed angles project inward and outward; the beauty of the carving is extraordinary, and wonderful is the appearance of the cavities which, overlaid with gold, produce the effect of rainbow more colourful than the one in the clouds. There is insatiable enjoyment here - not hidden, but on the surface. Not only those who direct their gaze to these things for the first time, but those who have often done so are struck with wonder and astonishment. Indeed, this Persian building is more delightful than the Laconian ones of Menelaus ${ }^{91}$.

It is assumed that this palace was built around the mid-twelfth century ${ }^{92}$. Its most characteristic element was - as can be deduced from the text - a muqarnas vault. The author, using a heavily rhetorical style, describes its complex form. $\mathrm{He}$ employs the common comparison of the vault with the heaven ( $\tau \tilde{\omega}$ oujpavozı $\delta \varepsilon \tilde{\varepsilon}$ óó $\varphi(\omega)$ and highlights the delightful - surpassing the rainbow - glow of gold

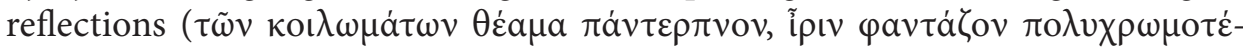

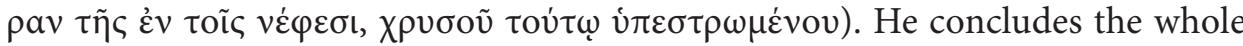
with a statement of the extraordinary beauty of the building, even more magnificent than the Menelaus' palace. In this way, Mesarites pointed to the Poet and his scheme of ekphrasis of dazzling residence of the mighty ruler ${ }^{93}$.

\footnotetext{
${ }^{90}$ Nikolaos Mesarites, Die Palastrevolution des Johannes Komnenos, ed. A. Heisenberg, Würzburg 1907 [= PKAGW], p. 44.27, 27-29, 34-36, p. 45.27, 1-9.

${ }^{91}$ C. Mango, The Art of the Byzantine..., p. 228-229.

${ }^{92}$ E.g. A. Walker, Middle Byzantine Aesthetics of Power and the Incomparability of Islamic Art. The Architectural Ekphraseis of Nikolaos Mesarites, Muq 27, 2010, p. 79-84; N. Asutay-Effenberger, "Muchrutas". Der seldschukische Schaupavillion im Grossen Palast von Konstantinopel, B 74, 2004, p. 313-324.

${ }^{93}[\ldots]$ oi $\delta \dot{e ̀ ~ i ̉ \delta o ́ v \tau \varepsilon \varsigma ~}$

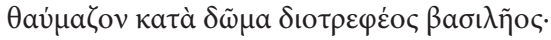

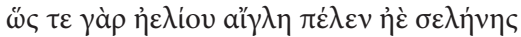

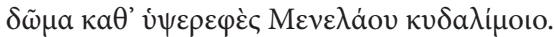

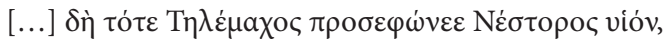

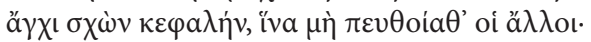

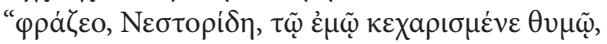

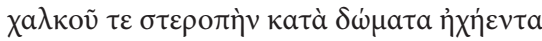


To summarize the remarks on the significance of gold in Byzantine ekphraseis, and at the same time indicate how long-lasting - reaching even beyond the fall of Constantinople - the inclination for gleaming and costly materials, including gold, was, it is proper to cite the passage on the Pammakaristos Church from the History of the Patriarchate of Constantinople from 1454 to 1578 (Патрцархıкทे

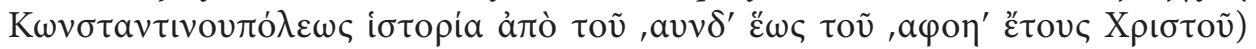
which was written by Manuel Malaxos (died ca. 1580):

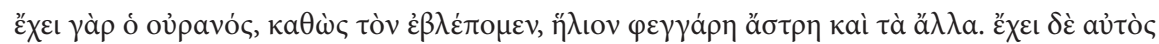

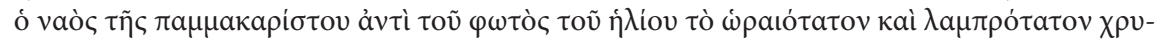

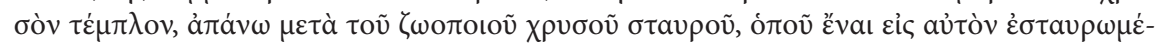

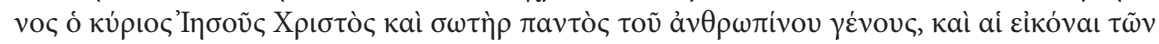

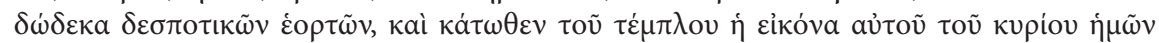

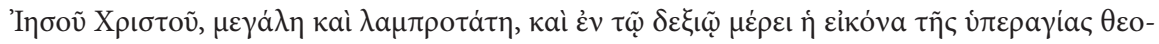

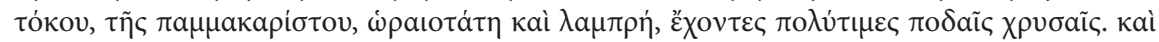

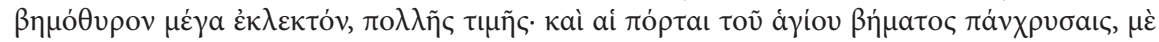

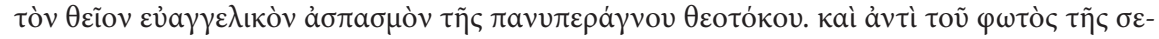

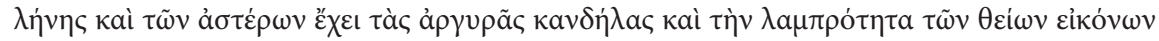

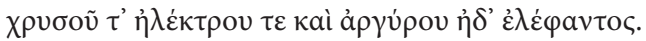

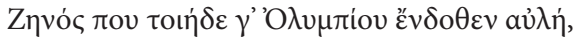

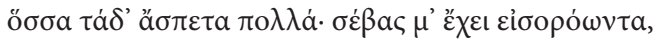

Homeri Odyssea, 4.43-46, 4.69-75, ed. P. von DER MüHLL, Basel 1962 (cetera: HoMER);

$[\ldots]$ aủià $\rho ' O \delta v \sigma \sigma \varepsilon \dot{c} \varsigma$

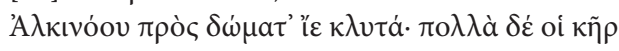

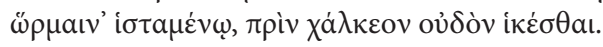

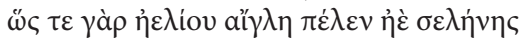

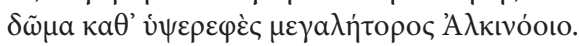

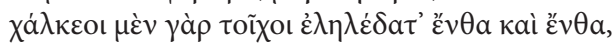

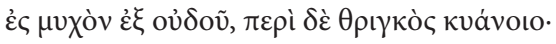

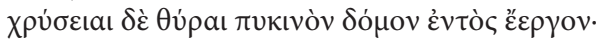

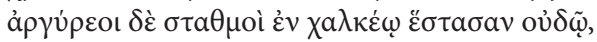

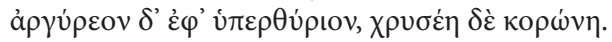

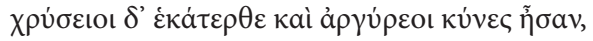

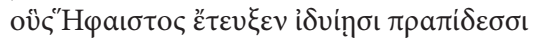

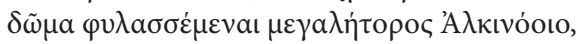

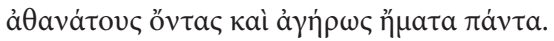

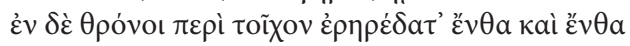

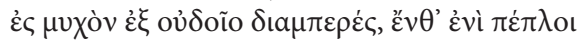

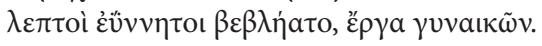

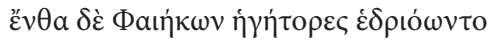

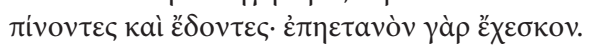

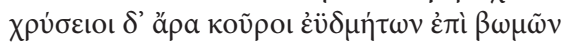

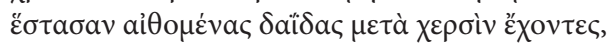

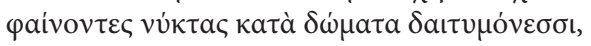
HOMER, 7.81-102. 


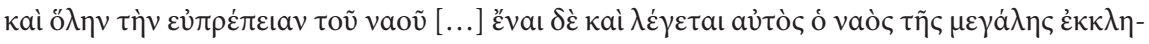

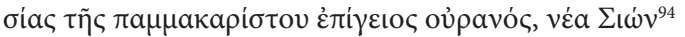

The sky - when we look at it - has the sun, moon, stars and other [celestial bodies]. In turn, this church of the All-Blessed instead of the light of the sun has the most beautiful and brightest golden templon with a life-giving and golden cross on the top, where the crucified Jesus Christ, Lord and Saviour of all mankind, is set, as well as the representation of the Twelve Great Feasts, and below the image of Our Lord Jesus Christ, great and brightest, and on the right, the image of the All-Blessed Virgin Mary, the most beautiful and bright: both have extremely valuable golden podeai. [There are] also gates to the sanctuary, really excellent and of great value; the door wings of the holy sanctuary [are] all gold and with the evangelical salutation of the Holy Mother of God. Instead of moonlight and stars, it has silver candlesticks and the splendour of sacred images, and all the glory of the shrine. [...] And this church is called the great church of the All-Blessed and is the heaven on earth, the new Zion.

Gold in Byzantine texts appears primarily as one of the most beautiful materials available to artists. Its beauty lies in its glow and colour, although despite the dazzling appearance, some authors stated that multi-coloured marbles are more

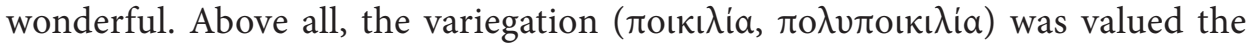
most. It was the main feature of the "jeweled aesthetics" developed in late antiquity and carried on by Byzantines. Byzantine writers relatively rarely referred to symbolic issues. For instance, in an ekphrasis of an icon of Virgin and Christ written by John Eugenikos (ca. 1400 - ca. 1453), we read that a gold colour of Christ's cloak indicates his divine nature ${ }^{95}$. A similar interpretation of the significance of gold we find in an epigram associated with Manuel Philes (ca. 1275-1345). He explains there that a silver gilded revetment of an icon designates spiritual features of the depicted Virgin ${ }^{96}$. The same motive is in an epigram on a bronze gilded statue of the charioteer Porphyrios: gold is referred to the merits of the famous athlete ${ }^{97}$. What is more important, for Byzantine authors, wonderful aesthetic properties of gold could also have a symbolic meaning. Nonetheless, they more frequently used to discuss aesthetic questions. Then, it seems that these matters need more attention of researchers because now they are rather neglected. In closing, it should also be added that highly appreciated visual effects created

\footnotetext{
${ }^{94}$ Manuel Malaxus, Historia politica Constantinopoleos (a 1454 usque ad 1578 annum Christi), 7-22, 7-9, [in:] Historia Politica et Patriarchica Constantinopoleos, ed. I. Bekker, Bonn 1849 [= CSHB, 32], p. 203-204.

${ }^{95}$ See Anecdota nova, ed. J.F. Boissonade, Paris 1844, p. 335-340. See as well G. Galavaris, The Stars of the Virgin. An Ekphrasis of an Ikon of the Mother of God, ECR 1, 1966, p. 364-369 (reprinted in: G. Galavaris, Colours, Symbols, Worship. The Mission of the Byzantine Artist, London 2012).

${ }^{96}$ See Manuelis Philae carmina inedita, 35, ed. A. Martini, Napoli 1900. See as well H. Maguire, Originality..., p. 110.

${ }^{97}$ See The Greek Anthology, vol. V, Book 13: Epigrams in Various Metres. Book 14: Arithmetical Problems, Riddles, Oracles. Book 15: Miscellanea. Book 16: Epigrams of the Planudean Anthology Not in the Palatine Manuscript, 15.46, ed. W.R. Paton, London-New York 1918 [= LCL, 86]. See as well A. Cameron, Porphyrius the Charioteer, Oxford 1973, p. 96-116.
} 
on gold surfaces are not only associated with diverse conceptual meanings but also with technical aspects which pertain to, among others, various methods of gilding and polishing. It is very important problem due to its direct impact on a final shape of works of art. This issue, however, is the subject for a different paper.

\section{Bibliography}

\section{Primary Sources}

Accounts of Medieval Constantinople. The Patria, trans. A. Berger, Cambridge Mass.-London 2013 [= Dumbarton Oaks Medieval Library, 24].

Anecdota nova, ed. J.F. Boissonade, Paris 1844.

Anthologia Graeca, vol. I, ed. H. BЕскву, München 1965.

BAsile de CÉsarée, Homélies sur l'hexaéméron, ed. S. Giet, Paris 1968 [= Sources chrétiennes, 26 bis].

Choricii Gazaei opera, ed. R. Foerster, E. Richtsteig, Leipzig 1929 [= Bibliotheca scriptorum Graecorum et Romanorum Teubneriana].

Chronographiae quae Theophanis Continuati nomine fertur Liber quo Vita Basilii Imperatoris amplectitur, ed. I. ŠEvCENKo, Berlin-Boston 2011 [= Corpus fontium historiae byzantinae. Series Berolinensis, 42].

Claudian, On Stilicho's Consulship 2-3, [in:] Claudian, On Stilicho's Consulship 2-3. Panegyric on the Sixth Consulship of Honorius. The Gothic War. Shorter Poems. Rape of Proserpina, vol. II, ed. M. Platnauer, Cambridge Mass. 1922 [= Loeb Classical Library, 136], https://www.loebclassics.com/view/claudian_claudianus-shorter_poems/1922/pb_LCL136.175.xml

Claudian, Panegyric on Probinus and Olybrius, [in:] Claudian, Panegyric on Probinus and Olybrius. Against Rufinus 1 and 2. War against Gildo. Against Eutropius 1 and 2. Fescennine Verses on the Marriage of Honorius. Epithalamium of Honorius and Maria. Panegyrics on the Third and Fourth Consulships of Honorius. Panegyric on the Consulship of Manlius. On Stilicho's Consulship 1, vol. I, ed. M. Platnauer, Cambridge Mass. 1922 [= Loeb Classical Library, 135].

Claudian, Panegyric on the Fourth Consulships of Honorius, [in:] Claudian, Panegyric on Probinus and Olybrius. Against Rufinus 1 and 2. War against Gildo. Against Eutropius 1 and 2. Fescennine Verses on the Marriage of Honorius. Epithalamium of Honorius and Maria. Panegyrics on the Third and Fourth Consulships of Honorius. Panegyric on the Consulship of Manlius. On Stilicho's Consulship 1, vol. I, ed. M. Platnauer, Cambridge Mass. 1922 [= Loeb Classical Library, 135].

Claudian, Panegyric on the Sixth Consulship of Honorius, [in:] Claudian, On Stilicho's Consulship 2-3. Panegyric on the Sixth Consulship of Honorius. The Gothic War. Shorter Poems. Rape of Proserpina, vol. II, ed. M. Platnauer, Cambridge Mass. 1922 [= Loeb Classical Library, 136], https://www.loebclassics.com/view/claudian_claudianus-shorter_poems/1922/pb_LCL136.175.xml

Claudian, Rape of Proserpina, [in:] Claudian, On Stilicho's Consulship 2-3. Panegyric on the Sixth Consulship of Honorius. The Gothic War. Shorter Poems. Rape of Proserpina, vol. II, ed. M. PLATNAuer, Cambridge Mass. 1922 [= Loeb Classical Library, 136], https://www.loebclassics.com/ view/claudian_claudianus-shorter_poems/1922/pb_LCL136.175.xml

Constantine of Rhodes, On Constantinople and the Church of the Holy Apostles, ed. L. James, I. Vassis, trans. V. Dimitropoulou, L. James, R. Jordan, Farnham 2012. 
Diēgēsis peri tēs Agias Sophias, [in:] Scriptores originum Constantinopolitanarum, vol. I, ed. T. PREGER, Leipzig 1901.

Digenis Akritis, The Grottaferrata and Escorial versions, ed. E. Jefrreys, Cambridge 1998 [= Cambridge Medieval Classics, 7].

Etymologicum Gudianum, vol. I, ed. E.L. De Stefani, Leipzig 1909 [= Bibliotheca scriptorum Graecorum et Romanorum Teubneriana].

Etymologicum Magnum, ed. T. GAISFord, Oxford 1848.

Etymologicum Symeonis ( $\Gamma-E)$, ed. D. BALDI, Turnhout 2013 [= Corpus christianorum, Series graeca, 79].

Eugenius Panormitanus, In imaginem Chrysostomi, [in:] Versus Iambici, ed. M. Gigante, Palermo 1964 [= Testi e Monumenti, 10].

Euphémie de Chalcédoine. Légendes byzantines, ed. F. Halkin, Bruxelles 1965 [= Subsidia hagiographica, 41].

Eusebius Werke, vol. I.1, Über das Leben des Kaisers Konstantin, ed. F. Winkelmann, Berlin 1975 [= Die griechischen christlichen Schriftsteller der ersten [drei] Jahrhunderte].

Flavius Cresconius Corippus, In laudem Iustini Augusti minoris. Libri IV, ed. Av. Cameron, London 1976.

The Greek Anthology, vol. V, Book 13: Epigrams in Various Metres. Book 14: Arithmetical Problems, Riddles, Oracles. Book 15: Miscellanea. Book 16: Epigrams of the Planudean Anthology Not in the Palatine Manuscript, ed. W.R. Paton, London-New York 1918 [= Loeb Classical Library, 86].

Gregorius Nyssenus, De sancto Theodoro, [in:] Patrologiae cursus completus, Series graeca, vol. XLVI, ed. J.-P. Migne, Paris 1863, col. 735-748.

Homeri Odyssea, ed. P. vON DER MüHLL, Basel 1962.

The Homilies of Photius, Patriarch of Constantinople, trans., praef. C. MAngo, Cambridge Mass. 1958 [= Dumbarton Oaks Studies, 3].

Iohannis Zonarae lexicon ex tribus codicibus manuscriptis, vol. I, ed. J.A.H. Tittmann, Leipzig 1808.

Leonis VI Sapientis Imperatoris Byzantini Homiliae, ed. T. Antonopoulou, Turnhout 2008 [= Corpus christianorum, Series graeca, 63].

Liudprand de Crémone, Antapodosis, [in:] Liudprand de Crémone, Euvres, ed. F. Bougard, Paris 2015 [= Sources d'histoire mediévale publiées par L'Institut de Recherche et d'Histoire des Textes, 41].

LuCian, The Hall, [in:] Lucian, Phalaris. Hippias or The Bath. Dionysus. Heracles. Amber or The Swans. The Fly. Nigrinus. Demonax. The Hall. My Native Land. Octogenarians. A True Story. Slander. The Consonants at Law. The Carousal (Symposium) or The Lapiths, vol. I, ed. A.M. HARmon, Cambridge Mass. 1913 [= Loeb Classical Library, 14], https://doi.org/10.4159/DLCL.lucian-hippias_ bath.1913

Mango C., The Art of the Byzantine Empire 312-1453, Toronto-Buffalo-London 2013 [= Medieval Academy Reprints for Teaching, 16].

Manuel Malaxus, Historia politica Constantinopoleos (a 1454 usque ad 1578 annum Christi), [in:] Historia Politica et Patriarchica Constantinopoleos, ed. I. Bekker, Bonn 1849 [= Corpus scriptorum historiae byzantinae, 32].

Manuelis Philae carmina inedita, ed. A. Martini, Napoli 1900.

Michaelis Pselli Chronographia, ed. D.R. ReInsch, Berlin-Boston 2014 [= Millennium-Studien. Studien zu Kultur und Geschichte des ersten Jahrtausends n. Chr. / Studies in the Culture and History of the First Millennium C.E., 51]. 
Niceforo Basilace, Progimnasmi e monodie, ed. A. Pignani, Napoli 1983 [= Byzantina et Neohellenica Neapolitana, 10].

Nicetae Choniatae historia, pars prior, ed. J. van Dieten, Berlin 1975 [= Corpus fontium historiae byzantinae. Series Berolinensis, 11.1].

Nicola Callicle, Carmi, ed. R. Romano, Napoli 1980 [= Byzantina et Neohellenica Neapolitana, 8].

Nicolai progymnasmata, ed. J. Felten, Leipzig 1913 [= Rhetores Graeci, 11; Bibliotheca scriptorum Graecorum et Romanorum Teubneriana].

Nikolaos Mesarites, Die Palastrevolution des Johannes Komnenos, ed. A. Heisenberg, Würzburg 1907 [= Programm des K. Alten Gymnasiums zu Würzburg für das Studienjahr 1906-1907].

Paulus Silentiarius, Descriptio Sanctae Sophiae, [in:] Paulus Silentiarius, Descriptio Sanctae Sophiae, Descriptio Ambonis, ed. C. DE Stefani, Berlin-New York 2010 [= Bibliotheca scriptorum Graecorum et Romanorum Teubneriana], https://doi.org/10.1515/9783110239072

Plotini opera, vol. I, Porphyrii vita Plotini et enneades I-III, ed. P. Henry, H.-R. Schwyzer, Leiden 1951 [= Museum Lessianum. Series philosophica, 33].

Procopii Caesarensis opera omnia. De aedificiis, vol. IV, ed. J. HAURY, rec. G. WirTh, Leipzig 1964 [= Bibliotheca scriptorum Graecorum et Romanorum Teubneriana].

Procopii Caesarensis opera omnia. De bellis libri, vol. II, ed. J. Haury, rec. G. Wirth, Leipzig 1963 [= Bibliotheca scriptorum Graecorum et Romanorum Teubneriana].

Procopii Caesarensis opera omnia. Historia qvae dicitvr arcana, vol. III, ed. J. HAURY, rec. G. WirTH, Leipzig 1963 [= Bibliotheca scriptorum Graecorum et Romanorum Teubneriana].

Procopius, On Buildings, trans. H.B. Dewing, G. Downey, Cambridge Mass.-London 1954 [= Loeb Classical Library, 343].

Progymnasmata. Greek Textbooks of Prose Composition and Rhetoric, trans., praef. G.A. Kennedy, Atlanta 2003 [= Writings from the Greco-Roman World, 10].

The Progymnasmata of Ioannes Geometres, ed. A.R. LitTlewood, Amsterdam 1972.

Rhetores Graeci, vol. I, ed. C. WALZ, Stuttgart 1832.

The Rhetorical Exercises of Nikephoros Basilakes. "Progymnasmata" from Twelfth-Century Byzantium, ed., trans. J. Beneker, C.A. Gibson, Cambridge Mass.-London 2016 [= Dumbarton Oaks Medieval Library, 43].

Sidonius, Poems and Letters, vol. I, ed. W.B. Anderson, Cambridge Mass. 1936 [= Loeb Classical Library, 296], https://doi.org/10.4159/DLCL.sidonius-poems.1936

The Suda on Line, http://www.stoa.org/sol/

Theodoros Prodromos, Historische Gedichte, ed. W. Hörandner, Wien 1974 [= Wiener byzantinistische Studien, 11].

Tou autou agiōtatou Phōtiou archiepiskopou Kōnstantinoupoleōs homilia, rētheisa ōs en ekphrasei tou en tois basileiois periōnymou naou, [in:] Phōtiou Homiliai, ed. B. LaOurdas, Thessalonikē 1959

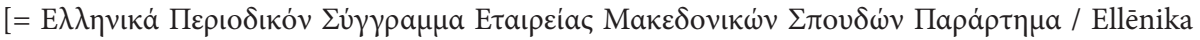
Periodikon Syggramma Etaireias Makedonikōn Spoudōn Parartēma, 12].

Tou autou peri noètou kallous, [in:] Michaelis Pselli philosophica minora, vol. II, ed. D.J. O’MeArA, Leipzig 1989 [= Bibliotheca scriptorum Graecorum et Romanorum Teubneriana]. 


\section{Secondary Literature}

Asutay-Effenberger N., "Muchrutas". Der seldschukische Schaupavillion im Grossen Palast von Konstantinopel, "Byzantion. Revue internationale des études byzantines" 74, 2004, p. 313-324.

AwIERINCEW S., Złoto w systemie symboli kultury wczesnobizantyjskiej, [in:] S. AwIERINCEW, Na skrzyżowaniu tradycji. Szkice o literaturze i kulturze wczesnobizantyjskiej, trans. et ed. D. UlickA, Warszawa 1988, p. 175-201.

Bakirtzis C., Rotunda, [in:] Mosaics of Thessaloniki $4^{\text {th }}-14^{\text {th }}$, ed. C. Bakirtzis, trans. A. Doumas, Athens 2012, p. 51-117.

Bakirtzis C., Mastora P., Are the Mosaics in the Rotunda into Thessaloniki Linked to its Conversion to a Christian Church?, "Ниш и Византија" / "Niš i Vizantija” 9, 2011, p. 33-46.

BARTSCH S., ElSNER J., Introduction. Eight Ways of Looking at an Ekphrasis, "Classical Philology” 102.1, 2007, p. I-VI, https://doi.org/10.1086/521128

Betancourt R., Sight, Touch, and Imagination in Byzantium, Cambridge 2018, https://doi.org/10.1017/ 9781108344067

Bolman E.S., Late Antique Aesthetics, Chromophobia and the Red Monastery, Sohag, Egypt, "Eastern Christian Art" 3, 2006, p. 1-24, https://doi.org/10.2143/ECA.3.0.2018699

Bolman E.S., Painted Skins. The Illusions and Realities of Architectural Polychromy, Sinai and Egypt, [in:] Approaching the Holy Mountain. Art and Liturgy at St Catherine's Monastery in the Sinai, ed. S.E.J. Gerstel, R.S. Nelson, Turnhout 2010 [= Cursor mundi, 11], p. 119-140.

Bosselmann-Ruickiıe A., Byzantinischer Schmuck des 9. bis frühen 13. Untersuchungen zum metallenen dekorativen Körperschmuck der mittelbyzantinischen Zeit anhand datierter Funde, Wiesbaden 2011 [= Spätantike - Frühes Christentum - Byzanz, 28].

Brubaker L., Perception and Conception. Art, Theory and Culture in Ninth-Century Byzantium, "Word \& Image" 5, 1989, p. 19-32, https://doi.org/10.1080/02666286.1989.10435392

Brubaker L., Talking about the Great Church. Ekphrasis and the "Narration on Hagia Sophia", "Byzantinoslavica. Revue internationale des études byzantines" 69.3, 2011, p. 80-87.

ВҮČкоv V.V., Malaja istorija vizantijskoj èstetiki, Kiev 1991.

ByČKov V.V., Vizantijskaja èstetika. Teoretičeskie problemy, Moskva 1977.

Cameron A., Porphyrius the Charioteer, Oxford 1973.

Carruthers M., The Experience of Beauty in the Middle Ages, Oxford 2013, https://doi.org/10.1093/ acprof:osobl/9780199590322.001.0001

Сıсноска Н., Teoria retoryki bizantyńskiej, Warszawa 1994.

Constantinople. Archaeology of a Byzantine Megapolis. Final Report on the Istanbul Rescue Archaeology Project 1998-2004, ed. K. DARK, F. ÖzGüMÜş, Oxford-Oakville 2013.

Cox Miller P., The Corporeal Imagination. Signifying the Holy in Late Ancient Christianity, Philadelphia 2009, https://doi.org/10.9783/9780812204681

Cox Miller P., "The Little Blue Flower Is Red". Relics and the Poetizing of the Body, "Journal of Early Christian Studies" 8.2, 2000, p. 213-236, https://doi.org/10.1353/earl.2000.0030

Durand J., Precious-Metal Icon Revetments, [in:] Byzantium. Faith and Power (1261-1557), ed. H.C. Evans, New York-New Haven 2004, p. 243-251.

EAstmond A., An Intentional Error? Imperial Art and "Mis"-Interpretation under Andronikos I Komnenos, “The Art Bulletin” 76, 1994, p. 502-510, https://doi.org/10.1080/00043079.1994.10786600 
ELSNER J., Introduction. The Genres of Ekphrasis, "Ramus. Critical Studies in Greek and Roman Literature" 31.1-2, 2002, p. 1-18, https://doi.org/10.1017/S0048671X00001338

Elsner J., Late Antique Art. The Problem of the Concept and the Cumulative Aesthetic, [in:] Approaching Late Antiquity. The Transformation from Early to Late Empire, ed. S. SwaIn, M. Edwards, Oxford 2006, p. 271-309, https://doi.org/10.1093/acprof:oso/9780199297375.003.0011

Galavaris G., The Stars of the Virgin. An Ekphrasis of an Ikon of the Mother of God, "Eastern Churches Review" 1, 1966, p. 364-369.

Glossarium ad scriptores mediae et infimae latinitatis, vol. VI, ed. C. DU Fresne DU CANGE, Niort 1883-1887.

GoldHILL S., What Is Ekphrasis for?, “Classical Philology” 102.1, 2007, p. 1-19, https://doi.org/10.1086/ 521129

Grabar A., Plotin et les origines de l'esthétique médiévale, [in:] A. Grabar, Les origines de l'esthétique médiévale, ed. G. Dagron, Paris 1992, p. 29-87.

Grabar A., Les revêtements en or et en argent des icônes byzantines du Moyen Âge, Venise 1975.

Grotowsкi P.Ł., O sztuce cytowania - chresis jako źródło w badaniach nad recepcja idei obrazu w Bizancjum, [in:] Hypomnemata Byzantina. Prace ofiarowane Maciejowi Salamonowi, ed. J. BonareK, S. Turlej, Piotrków Trybunalski 2017, p. 55-94.

Grünbart M., Zur Kulturgeschichte des Goldes, [in:] Gold und Blei. Byzantinische Kostbarkeiten aus dem Münsterland, ed. M. GrünBART, Wien 2012, p. 53-66.

Gurtler G.M., Plotinus and Byzantine Aesthetics, “The Modern Schoolman. A Quarterly Journal of Philosophy" 66.4, 1989, p. 275-284, https://doi.org/10.5840/schoolman198966453

Haldane J., Medieval Aesthetics, [in:] The Routledge Companion to Aesthetics, ed. B. Gaut, D. McIver Lopes, London 2013 [= Routledge Philosophy Companions], p. 25-35.

The Holy Apostles - A Lost Monument, a Forgotten Project, and the Presentness of the Past, ed. M. Mullett, R.G. Ousterhout, Washington D.C. 2020 [= Dumbarton Oaks Byzantine Symposia and Colloquia].

Intelligible Beauty. Recent Research on Byzantine Jewellery, ed. C. Entwistle, N. Adams, London 2010.

Ivanovici V., Divine Light through Earthly Colours. Mediating Perception in Late Antique Churches, [in:] Colour and Light in Ancient and Medieval Art, ed. C.N. Duckworth, A.E. SAssin, New York-London 2018, p. 81-91, https://doi.org/10.4324/9781315167435-7

Jaсову D., Silk Production, [in:] The Oxford Handbook of Byzantine Studies, ed. E. Jefrereys, J. HaLDON, R. CORMACK, Oxford 2008, p. 421-428.

James L., Color and Meaning in Byzantium, "Journal of Early Christian Studies" 11.2, 2003, p. 223-233, https://doi.org/10.1353/earl.2003.0027

James L., Constantine of Rhodes's Poem and Art History, [in:] Constantine of Rhodes, On Constantinople and the Church of the Holy Apostles, ed. L. James, I. Vassis, trans. V. Dimitropoulou, L. JaMES, R. JoRDAN, Farnham 2012, p. 131-222.

James L., Mosaics in the Medieval World. From Late Antiquity to the Fifteenth Century, Cambridge 2017, https://doi.org/10.1017/9780511997693

James L., Webв R., "To Understand Ultimate Things and Enter Secret Places". Ekphrasis and Art in Byzantium, "Art History" 14.1, 1991, p. 1-17, https://doi.org/10.1111/j.1467-8365.1991.tb00420.x

Janes D., God and Gold in Late Antiquity, Cambridge 2010.

Jenkins R.J.H., Mango C., The Date and Significance of the Tenth Homily of Photius, "Dumbarton Oaks Papers" 9/10, 1956, p. 125-140, https://doi.org/10.2307/1291094 
LANGE J., Et blad af koloritens historie (1893), [in:] Udvalgte Skrifter af Julius Lange, ed. G. BRANDES, P. Køвке, København 1901, p. 136-156.

LAZAREv V.N., Istorija vizantijskoj živopisi, vol. I, Moskva 1947.

L'Orange H.P., Art Forms and Civic Life in the Late Roman Empire, Princeton 1965.

Maguire H., Art and Eloquence in Byzantium, Princeton 1981.

Maguire H., Art and Text, [in:] The Oxford Handbook of Byzantine Studies, ed. E. Jefrreys, J. HaLDON, R. CORMACK, Oxford 2008, p. 721-730.

Maguire H., The Asymmetry of Text and Image in Byzantium, "Perspectives médiévales" 38, 2017, https://doi.org/10.4000/peme.12218

Maguire H., Nectar \& Illusion. Nature in Byzantine Art and Literature, Oxford 2016 [= Onassis Series in Hellenic Culture].

Maguire H., Originality in Byzantine Art, [in:] Originality in Byzantine Literature, Art and Music. A Collection of Essays, ed. A.R. LittLewood, Oxford 1995 [= Oxbow Monograph, 50], p. 101-114.

Maguire H., The Realities of Ekphrasis, "Byzantinoslavica. Revue internationale des études byzantines" 69.3, 2011, p. 7-19.

Maguire H., Truth and Convention in Byzantine Descriptions of Works of Art, "Dumbarton Oaks Papers" 28, 1974, p. 113-140, https://doi.org/10.2307/1291357

Mango C., Antique Statuary and the Byzantine Beholder, "Dumbarton Oaks Papers" 17, 1963, p. 64-70, https://doi.org/10.2307/1291190

Mango C., Parker J., A Twelfth-Century Description of St. Sophia, "Dumbarton Oaks Papers" 14, 1960, p. 233-245, https://doi.org/10.2307/1291152

Mariev S., Introduction. Byzantine Aesthetics, [in:] Aesthetics and Theurgy in Byzantium, ed. S. MARIEv, W.-M. STOCK, Berlin-Boston 2013 [= Byzantinisches Archiv, 25], p. 2-11, https://doi. org/10.1515/9781614512615

Mathew G., Byzantine Aesthetics, London 1963.

Michelēs P.A., Aisthētikè theōrēsē tēs byzantinēs technēs, Athēna 2006.

Michelis P.A., L'esthétique d'Hagia-Sophia, Faenza 1963.

Michelis P.A., Neo-Platonic Philosophy and Byzantine Art, "The Journal of Aesthetics and Art Criticism" 11, 1952, p. 21-45, https://doi.org/10.2307/426617

Mullett M., Ouserhout R., The Holy Apostles. Dumbarton Oaks Symposium, 24-26 April 2015, "Dumbarton Oaks Papers" 70, 2016, p. 325-326.

Muthesius A., Byzantine Silk Weaving AD 400 to AD 1200, Vienna 1997.

Muthesius A., Essential Processes, Looms, and Technical Aspects of the Production of Silk Textiles, [in:] The Economic History of Byzantium. From the Seventh through the Fifteenth Century, vol. I, ed. A.E. Laiou, Washington 2002 [= Dumbarton Oaks Studies, 39], p. 147-168.

Muthesius A., Studies in Silk in Byzantium, London 2004.

NeLson R.S., To Say and to See. Ekphrasis and Vision in Byzantium, [in:] Visuality before and beyond the Renaissance. Seeing as Others Saw, ed. R.S. Nelson, Cambridge 2000, p. 143-168.

New Research on Late Byzantine Goldsmiths' Works (1 $3^{\text {th }}-15^{\text {th }}$ Centuries). Neue Forschungen zur spätbyzantininischen Goldschmiedekunst (13.-15. Jahrhundert), ed. A. Bosselmann-Ruickiı, Mainz 2019 [= Byzanz zwischen Orient und Okzident, 13].

Onians J., Abstraction and Imagination in Late Antiquity, "Art History" 3, 1980, p. 1-24, https://doi. org/10.1111/j.1467-8365.1980.tb00061.x 
Papaionnnou S., Byzantine Enargeia and Theories of Representation, "Byzantinoslavica. Revue internationale des études byzantines" 69, 2011, p. 48-60.

Papamastorakis T., The Display of Accumulated Wealth in Luxury Icons. Gift-Giving from the Byzantine Aristocracy to God in the Twelfth Century, [in:] Byzantines eikones. Techne, technikē kai technologia. Diethnes Symposio, Gennadeios Bibliothēkē, Amerikanikē Scholē Klasikōn Spoudōn, 20-21 Phebrouariou 1998, ed. M. BASILAKĒ, Ërakleio 2002, p. 35-49.

PAtterson ŠEvčenko N., Vita Icons and "Decorated" Icons of the Komnenian Period, [in:] Four Icons in the Menil Collection, ed. B. Davezac, Houston 1992, p. 57-69.

Pentcheva B.V., Hagia Sophia, Sound, Space, and Spirit in Byzantium, University Park 2017.

Pentcheva B.V., The Sensual Icon. Space, Ritual, and the Senses in Byzantium, University Park 2010.

Roberts M., The Jeweled Style. Poetry and Poetics in Late Antiquity, Ithaca 1989.

Różycka BryzeK A., Focjusz, patriarcha Konstantynopola, „Homilia X”, “Znak” 466.3, 1994, p. 57.

Schibille N., Hagia Sophia and the Byzantine Aesthetic Experience, Farnham 2014.

Smorąg Różycka M., Miejsce ekfrazy w bizantynistycznej historiografii artystycznej, "Vox Patrum. Antyk Chrześcijański” 70, 2018, p. 471-484, https://doi.org/10.31743/vp.3217

SQuire M., Ecphrasis. Visual and Verbal Interactions in Ancient Greek and Latin Literature, [in:] Oxford Handbooks Online, 2015, https://doi.org/10.1093/oxfordhb/9780199935390.013.58

SQUiRe M., Image and Text in Graeco-Roman Antiquity, Cambridge 2015.

Strzygowski J., Orient oder Rom. Beitrag zur Geschichte der spätantiken und frühchristlichen Kunst, Leipzig 1901.

Thомаs T.K., The Medium Matters. Reading the Remains of a Late Antique Textile, [in:] Reading Medieval Images. The Art Historian and the Object, ed. E. SeArs, T.K. Thomas, Ann Arbor 2002, p. 39-49.

Torp H., Considerations on the Chronology of the Rotunda Mosaics, [in:] The Mosaics of Thessaloniki Revisited. Papers from the 2014 Symposium at the Courtauld Institute of Art, ed. A. EAstmond, M. Hatzaki, Athens 2017, p. 35-47.

Torp H., La rotonde palatine à Thessalonique. Architecture et mosaïques, vol. I, Athènes 2018.

Walker A., Middle Byzantine Aesthetics of Power and the Incomparability of Islamic Art. The Architectural Ekphraseis of Nikolaos Mesarites, "Muqarnas. An Annual on the Visual Culture of the Islamic World" 27, 2010, p. 79-101, https://doi.org/10.1163/ej.9789004185111.i-448.30

Weвв R., The Aesthetics of Sacred Space. Narrative, Metaphor, and Motion in "Ekphraseis" of Church Buildings, "Dumbarton Oaks Papers" 53, 1999, p. 59-74, https://doi.org/10.2307/1291794

Wевв R., Ekphraseis of Buildings in Byzantium. Theory and Practice, "Byzantinoslavica. Revue internationale des études byzantines" 69.3, 2011, p. 20-32.

Weвв R., Ekphrasis Ancient and Modern. The Invention of a Genre, "Word \& Image" 15.1, 1999, p. 7-18, https://doi.org/10.1080/02666286.1999.10443970

Webв R., Ekphrasis, Imagination and Persuasion in Ancient Rhetorical Theory and Practice, Farnham 2009.

Zarras N., A Gem of Artistic Ekphrasis. Nicholas Mesarites' Description of the Mosaics in the Church of the Holy Apostles at Constantinople, [in:] Byzantium, 1180-1204. 'The Sad Quarter of a Century'?, ed. A. Simpson, Athens 2015, p. 261-282. 


\begin{abstract}
The abundance of gilding is considered to be a particularly characteristic feature of Byzantine art. This attribute can be confirmed by even a cursory analysis of works of art. In short, Byzantine artists used gold on a large scale, showing great technical skill. It is therefore quite surprising that this issue has not yet received a separate, comprehensive study. Admittedly, researchers recognize the presence of gold but unfortunately, they almost do not go beyond general observations. On the one hand, they emphasize the primary role of the symbolic meanings of gold, and, on the other, they indicate the high material value of this precious metal. These comments are usually very general and their authors rarely refer to specific primary sources. Their observations, however, speak more about present-day ideas about Byzantine culture than about it itself. The indicated problem is an important and extensive task to be done, hence this paper is only an outline of the most important questions, each of which requires a separate and in-depth study. Therefore, this synthetic article introduces the most basic points associated with the understanding of gold in Byzantium. For this purpose, selected examples of Byzantine texts in which their authors referred to gold in a strictly artistic context are analysed. Thus, the main thesis is as follows: in Byzantine painting, gold, one of the most important devices of artistic expression, was used on a large scale primarily for aesthetic reasons.
\end{abstract}

Keywords: Byzantine aesthetics, ekphrasis, gilding, mosaic, marble

Magdalena Garnczarska

Jagiellonian University

Institute of History of Art

ul. Grodzka 53

31-001 Kraków, Polska/Poland

magdalena.garnczarska@gmail.com 